\title{
UV-B Radiation as Abiotic Elicitor to Enhance Phytochemicals and Development of Red Cabbage Sprouts
}

\author{
Lorena Martínez-Zamora (D), Noelia Castillejo (D) and Francisco Artés-Hernández *(D) \\ Department of Agronomical Engineering \& Institute of Plant Biotechnology, Universidad Politécnica de \\ Cartagena, 30203 Cartagena, Murcia, Spain; lorena.martinez@upct.es (L.M.-Z.); noelia.castillejo@upct.es (N.C.) \\ * Correspondence: fr.artes-hdez@upct.es; Tel.: +34-968-325509
}

check for

updates

Citation: Martínez-Zamora, L.; Castillejo, N.; Artés-Hernández, F. UV-B Radiation as Abiotic Elicitor to Enhance Phytochemicals and Development of Red Cabbage Sprouts. Horticulturae 2021, 7, 567. https://doi.org/10.3390/

horticulturae7120567

Academic Editor: Hanne Kristine Sivertsen

Received: 22 November 2021 Accepted: 8 December 2021 Published: 9 December 2021

Publisher's Note: MDPI stays neutral with regard to jurisdictional claims in published maps and institutional affiliations.

Copyright: (c) 2021 by the authors. Licensee MDPI, Basel, Switzerland. This article is an open access article distributed under the terms and conditions of the Creative Commons Attribution (CC BY) license (https:/ / creativecommons.org/licenses/by/ $4.0 /)$.

\begin{abstract}
Background: The main objective of this study was to evaluate the effect of periodical UV-B illumination during red cabbage germination on morphological development and the phenolics and carotenoid accumulation. Methods: During a sprouting period of 10 days at $20{ }^{\circ} \mathrm{C}$ in darkness, seedlings received 5,10 , or $15 \mathrm{~kJ} \mathrm{~m}^{-2} \mathrm{UV}-\mathrm{B}$ (T5, T10, and T15) applied in four steps (25\% on days $3,5,7$, and 10). UV untreated sprouts were used as control (CTRL). After 10 days of germination, the sprouts were harvested and stored 10 days at $4{ }^{\circ} \mathrm{C}$ as a minimally processed product. Phenolic and carotenoid compounds were analysed $1 \mathrm{~h}$ after each UV-B application and on days $0,4,7$, and 10 during cold storage. Results: The longest hypocotyl length was observed in T10-treated sprouts. The total phenolic content (TPC), total flavonoid content (TFC), and total antioxidant capacity (TAC) increased during germination following a sigmoidal kinetic, especially in the UV-B-treated samples, which reported a dose-dependent behaviour. In this way, T10-treated sprouts increased the TPC by $40 \%$ after 10 days at $4{ }^{\circ} \mathrm{C}$ compared to CTRL, while TAC and TFC increased by 35 and $30 \%$, respectively. Carotenoids were enhanced with higher UV-B doses (T15). Conclusions: We found that UV-B stimulated the biosynthesis of bioactive compounds, and a dose of $10 \mathrm{~kJ} \mathrm{~m}^{-2} \mathrm{UV}-\mathrm{B}$, proportionally applied on days $3,5,7$, and 10 days, is recommended.
\end{abstract}

Keywords: ultraviolet; nutraceuticals; production; Brassica oleracea var. capita; phenols; antioxidants

\section{Introduction}

In recent years, food consumption habits have changed due to consumers' new lifestyle, which tends towards healthier foods. Therefore, the food demand is more oriented to diets based on fruit and vegetables, characterised by a high content of bioactive and nutritional compounds [1,2]. In this way, there is a current trend of eating minimally processed vegetables harvested in the first days of growth ( $<14$ days), commonly known as sprouted seeds. Indeed, they are becoming very popular worldwide because of their health benefits due to the high content of health-promoting compounds (carotenoids and phenolics) and the lack of additives. In particular, such health-promoting compounds are exponentially biosynthesised during germination, while the concentration of anti-nutritional compounds decreases [1]. In this sense, frequency consumption of sprouted seeds has been linked with a lower risk of chronic diseases [3], mainly due to their high concentration in nutraceutical compounds with potential health benefits $[1,4,5]$.

Brassica oleracea var. capitata f. Rubra (red cabbage) was used in this work as a model for studying sprouted seeds. Brassicas are widely known as a good source of antioxidant compounds, especially phenolics and flavonoids. In fact, cruciferous (cabbage family) sprouts are reported to be up to 10 -fold richer in nutraceutical compounds compared to the adult plant. For that reason, Brassicaceae sprouts have been incorporated into the gastronomy of some Mediterranean countries in recent years [6].

Light provides a key factor for biological responses during plant growth as the main energy source. Therefore, its intensity, wavelength, and application time are essential 
factors influencing plant development. The ultraviolet (UV) radiation acts from 100 to $400 \mathrm{~nm}$ of the electromagnetic spectrum [7,8]. High doses of UV-B radiation $(280-320 \mathrm{~nm})$ can produce harmful effects in DNA and several components of plants [9]. However, plant responses to UV-B radiation vary according to the received dose, UV-spectral composition, light direction, distance of the light source, acclimation time, plant genotype, and development stage [10]. Therefore, plant susceptibility to UV-B radiation depends on the balance between protection, mitigation, and damage. In this sense, low doses of UV-B radiation can be an important stimuli of the biosynthesis of secondary metabolites in plants [11]. In fact, barley acclimation to UV radiation results in an increased photoprotective capacity [10]. In this case, the oxidative stress triggered by exposure to UV-B is counteracted by the synthesis of secondary metabolites with important antioxidant abilities that compensate the impact of such oxidative processes [11].

In this sense, plants detect UV-B radiation through photoreceptors called ULTRAVIOLET B RESISTANCE LOCUS 8 (UVR8), which regulate the expression of key genes which induce the accumulation of reactive oxygen species (ROS) chelating compounds [12,13], which are also involved in the phytochemicals accumulation as non-photoreceptor-mediated responses [14]. This behaviour occurs when the UVR8 receptor interacts with CONSTITUTIVE PHOTOMORPHOGENESIS PROTEIN 1 (COP1) and then with protein ELONGATED HYPOCOTYL 5 (HY5). This UVR8-COP1-HY5 complex triggers the expression of the genes needed for the acclimation to UV-B radiation, such as genes encoding for enzymes of the phenylpropanoid pathway [15], flavonoid-glycosylation, ROS scavenging enzymes, and/or UV-induced morphogenic responses [16,17]. Through the regulation of these genes, defence and repair capacity of the plant are adjusted to allow the acclimation to UV-B [15]. In fact, the UVR8-COP1-HY5 pathway is the main signalling cascade involved in UV-B tolerance [17].

Recent studies have shown that the combination of moderate UV-B and UV-C treatments induced a higher content of phenolic compounds and glucosinolates after $72 \mathrm{~h}$ at $15{ }^{\circ} \mathrm{C}$ in broccoli by-products such as leaves and stems [18]. In addition, high UV-B treatment $\left(15 \mathrm{~kJ} \mathrm{~m}^{-2}\right)$, alone or combined with moderate UV-C illumination, increased the phytochemicals of broccoli edible florets with the highest glucosinolates after $72 \mathrm{~h}$ at $15^{\circ} \mathrm{C}$, which is important for the fresh product market [18]. Topcu et al. [19] concluded that pre-harvest UV-B treatments during the vegetative period is a promising tool for increasing the nutraceutical compounds in Brassicaceae, reporting that the glucosinolates in broccoli was substantially increased by UV-B treatments $\left(2.2,8.8\right.$, and $16.4 \mathrm{~kJ} \mathrm{~m}^{-2}$ day $\left.^{-1}\right)$.

The aim of the present research work was to study the effect of periodical UV-B illumination during red cabbage germination on the content of their main bioactive compounds (phenolics, antioxidants, flavonoids, and carotenoids). Likewise, the evolution of such healthpromoting compounds in the harvested sprouts was also assayed during a shelf-life period of 10 days at $4{ }^{\circ} \mathrm{C}$.

\section{Materials and Methods}

\subsection{Sprouting Conditions}

Red cabbage seeds (Brassica olearacea var. capita) (2 g per tray), provided by Intersemillas S.A. (Valencia, Spain), were rinsed twice (1 min each one). After that, the seeds were sown in a laminar flow hood. Seeds were sown on polypropylene trays $(17 \times 12 \times 5 \mathrm{~cm})$, using a layer of filter paper as support. To ensure a high relative humidity $(\mathrm{RH})$, we covered the trays with a $40 \mu \mathrm{m}$ biaxially oriented polypropylene film (PDS Group). A total of 168 trays were initially prepared: 6 trays per treatment $(4=$ CTRL, T5, T10, T15) and sampling days ( $7=3,5,7$, and 10 days of sprouting followed by 4,7 , or 10 day cold treatment).

Red cabbage seeds were germinated under darkness conditions for 10 days at $20{ }^{\circ} \mathrm{C}$ and $85 \% \mathrm{RH}$ in a growth chamber (Sanyo MLR-350 H, Osaka, Japan).

\subsection{UV-B Doses during Sprouting and Processing after Harvesting}

On days $3,5,7$, and 10 of the sprouting periods, trays with red cabbage sprouts were placed in the radiation chamber, $17.5 \mathrm{~cm}$ below the UV-B TL 40 W/01 RS lamps (Philips, 
Eindhoven, The Netherlands). The radiation chamber, previously described by FormicaOliveira et al., [20,21] included 6 UV-B lamps, which were switched off while treatments were not applied. The applied UV-B intensity of $7.90 \pm 0.35 \mathrm{~W} \mathrm{~m}^{-2}$ was measured using a LP 471 UV-B (Delta OHM, Padova, Italy) radiometer $(n=25)$, and the UV-B spectrum is shown in Figure S1. The intensities of UV lighting were kept constant, but the exposure time varied to create different UV doses:

- CTRL: no UV treatment was used as a control.

- T5: the sprouts received a total of $5 \mathrm{~kJ} \mathrm{~m}^{-2} \mathrm{UV}-\mathrm{B}$ at the end of germination using $1.25 \mathrm{~kJ} \mathrm{~m}^{-2}$ day $^{-1}$. For that, UV-B lamps were switched on for $2 \mathrm{~min} 42 \mathrm{~s}$ each day.

- T10: the sprouts received a total of $10 \mathrm{~kJ} \mathrm{~m}^{-2} \mathrm{UV}-\mathrm{B}$ at the end of the germination using $2.50 \mathrm{~kJ} \mathrm{~m}^{-2} \mathrm{day}^{-1}$. For that, UV-B lamps were switched on for $5 \mathrm{~min} 24 \mathrm{~s}$ each day.

- T15: the sprouts received a total of $15 \mathrm{~kJ} \mathrm{~m}^{-2} \mathrm{UV}-\mathrm{B}$ at the end of the germination using $3.25 \mathrm{~kJ} \mathrm{~m}^{-2}$ day $^{-1}$. For that, UV-B lamps were switched on for $8 \min 6 \mathrm{~s}$ each day.

The total UV-B dose received by the sum of each UV application was based on our previous experiments with Brassicaceae sprouts to reach maximum phenolics accumulation while minimising heating during the UV treatment [22]. CTRL samples were kept in the growth chamber under darkness conditions, while UV-B treatments were applied. One hour after each UV-B application (on days 3, 5, 7, and 10 of the germination period), the sprouts ( 6 trays per treatment-CTRL, T5, T10, and T15-) were immediately frozen at $-80^{\circ} \mathrm{C}$ and freeze-dried (Lyoquest-85, Telstar Technologies, Terrassa, Spain).

After the last UV treatment, the 10-day-old sprouts left unsampled were washed, sanitised with a $150 \mathrm{mg} \mathrm{L}^{-1}$ sodium hypochlorite solution $\left(5^{\circ} \mathrm{C}\right.$; $\left.\mathrm{pH}=6.5\right)$ for $1 \mathrm{~min}$, and then rinsed for $1 \mathrm{~min}$ at $5{ }^{\circ} \mathrm{C}$. The sprouts were then stored for 10 days at $4{ }^{\circ} \mathrm{C}$ in $280 \mathrm{~mL}$ polypropylene containers with lids under $90 \% \mathrm{RH}$ for 4,7 , or 10 days. Six trays per treatment were sampled on each day and freeze-dried until further analysis. The experimental design is schematised in Figure 1.

\subsection{Morphological Development during Growth}

Hypocotyl and root lengths as well as moisture content were determined. The hypocotyl and root lengths (10 sprouts from 3 randomly picked tray for each sample $=3$ independent biological replicates) were determined using the ImageJ software 1.8.0_172 [23].

Moisture was expressed as percentage (\%) and calculated using the following equation: $(\mathrm{FW}-\mathrm{DW}) / \mathrm{FW} \times 100$; with FW: fresh weight and DW: dry weight.

\subsection{Extraction of Bioactive Compounds}

Following the method described by Martínez-Zamora et al. [24], we placed freezedried sprouts $(50 \mathrm{mg})$ in plastic tubes with $6 \mathrm{~mL}$ methanol/ $\mathrm{H}_{2} \mathrm{O}(80: 20, v / v)$. For each treatment, three biological replicates (sprouts from 3 trays) were extracted in an orbital shaker where the samples were shaken for $1 \mathrm{~h}$, at $4{ }^{\circ} \mathrm{C}$, in darkness. The supernatant was collected after a centrifugation at $3220 \times \mathrm{g}$ for $10 \mathrm{~min}$ at $5{ }^{\circ} \mathrm{C}$ to measure total phenolic content (TPC), total flavonoid content (TFC), and total antioxidant capacity (TAC) using three replicates for each of the analysed compounds.

The method of Singleton and Rossi [25] with some modifications was performed to determine TPC, as described by Martínez-Zamora et al. [26]. For that, $0.019 \mathrm{~mL}$ of the sample extract was mixed with $0.029 \mathrm{~mL}$ of $1 \mathrm{~mol} \mathrm{~L}^{-1}$ Folin-Ciocalteu reagent and $0.192 \mathrm{~mL}$ of $0.4 \% \mathrm{Na}_{2} \mathrm{CO}_{3}$ and $2 \% \mathrm{NaOH}$. The absorbance was measured at $750 \mathrm{~nm}$ using a microplate reader (Tecan Infinite M200; Tecan Trading AG, Männedorf, Switzerland) after $1 \mathrm{~h}$ of incubation under darkness conditions. The TPC was expressed as mg chlorogenic acid equivalents (CAE) $\mathrm{g}^{-1} \mathrm{DW}$ using the following chlorogenic acid standard curve: $\mathrm{y}=0.32 \times(-0.01) ; \mathrm{R}^{2}>0.99$. 


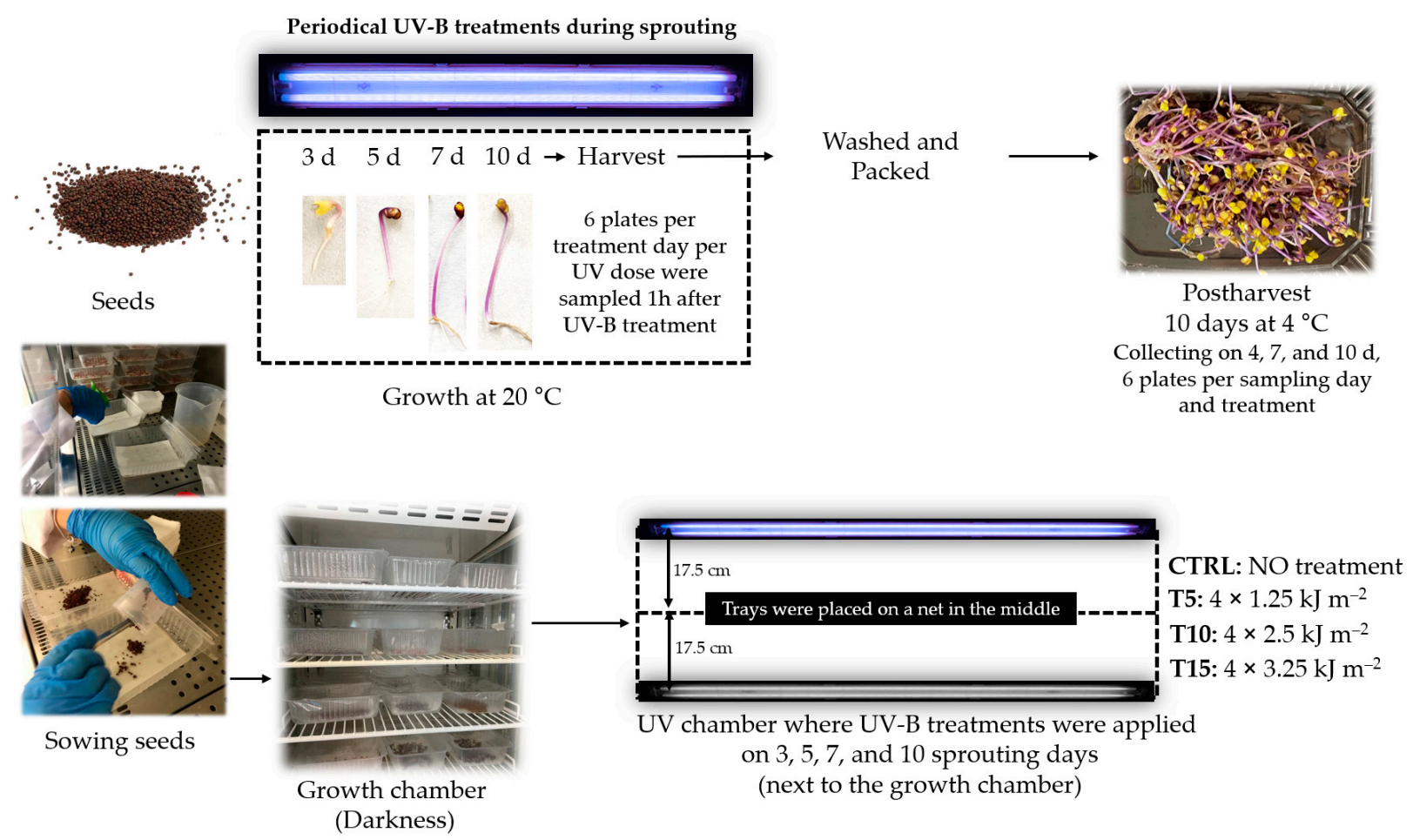

Figure 1. Experimental design evaluating the effect of periodical UV-B illumination on the physiology of red cabbage spouts and the content of bioactive compounds (phenolics, flavonoids, and carotenoids) both during germination and during cold storage. Seedlings received 5, 10, or $15 \mathrm{~kJ} \mathrm{~m}^{-2} \mathrm{UV}-\mathrm{B}$ (T5, T10, and T15) divided into four doses applied on 3, 5, 7 and 10 days of the sprouting period (10 days at $20^{\circ} \mathrm{C}$ in darkness). UV-untreated sprouts were used as control (CTRL). At the end of the germination (10 days), the sprouts were harvested and stored 10 days at $4{ }^{\circ} \mathrm{C}$. Sprout development and studied bioactive compounds were analysed after $1 \mathrm{~h}$ of each UV-B application (sprouting period) and on $0,4,7$, and 10 days at $4{ }^{\circ} \mathrm{C}$ (shelf-life study).

TFC was determined by following the method described by Hamed et al. [27]. Briefly, $0.030 \mathrm{~mL}$ of extract was mixed with $0.080 \mathrm{~mL}$ of aluminium chloride $\left(20 \mathrm{~g} \mathrm{~L}^{-1}\right)$. The samples were shaken for $30 \mathrm{~s}$ and then incubated in darkness for $1 \mathrm{~h}$. After that, the reaction absorbance was measured at $415 \mathrm{~nm}$. TFC was expressed as $\mathrm{mg}$ rutin equivalents (RE) $\mathrm{g}^{-1}$ of DW using the following rutin standard curve: $\mathrm{y}=1.83 \times 0.01 ; \mathrm{R}^{2}>0.99$.

TAC was analysed using DPPH ${ }^{\bullet}$ (2,2-diphenyl-1-picrylhydrazyl) [28], FRAP (ferric reducing ability power) [29], and $\mathrm{ABTS}^{\bullet}+\left(2,2^{\prime}\right.$-azino-bis(3-ethylbenzothiazoline-6-sulfonic acid)) [28] assays. DPPH ${ }^{\bullet}$ assay was performed by adding $0.194 \mathrm{~mL}^{\circ} \mathrm{DPPH}^{\bullet}(700 \mu \mathrm{M})$ solution to $0.021 \mathrm{~mL}$ of sprout extract. After $30 \mathrm{~min}$ incubation in darkness, absorbance was measured at $515 \mathrm{~nm}$. TAC was expressed as mg trolox equivalents (TE) $\mathrm{g}^{-1}$ of DW using the following trolox standard curve: $y=0.20 \times(-0.05) ; R^{2}>0.99$. The FRAP method was conducted using a daily solution containing sodium acetate buffer ( $\mathrm{pH} 3.6), 10 \mathrm{mM}$ TPTZ (2,4,6-Tris(2-pyridyl)-s-triazine) solution (in $40 \mathrm{mM} \mathrm{HCl}$ ), and $20 \mathrm{mM} \mathrm{FeCl}_{3}$ (10:1:1; $v / v / v$ ). Then, $0.198 \mathrm{~mL}$ of FRAP solution was added to $0.006 \mathrm{~mL}$ of sprout extract, and the mixture was incubated for $40 \mathrm{~min}$ in darkness, with TAC measured by changes in absorbance at $593 \mathrm{~nm}$. TAC was expressed as $\mathrm{mg} \mathrm{TE}^{-1}$ of DW using the following Trolox standard curve: $\mathrm{y}=0.41 \times(-0.01) ; \mathrm{R}^{2}>0.99$. The $\mathrm{ABTS} \boldsymbol{C}^{\bullet}$ assay was performed by adding $0.2 \mathrm{~mL}$ of the activated ABTS + solution $(32 \mu \mathrm{M})$ to $0.011 \mathrm{~mL}$ of sprout extract in a 96-well plate. TAC was assessed by changes in absorbance at $414 \mathrm{~nm}$ after 20 min under darkness conditions. Obtained data were expressed as $\mathrm{mg}$ of TE $\mathrm{g}^{-1} \mathrm{DW}$ using the following Trolox standard curve: $\mathrm{y}=0.15 \times(-0.02) ; \mathrm{R}^{2}>0.99$.

\subsection{Extraction and Determination of Total Carotenoids Content}

Sample preparation was performed according to Castillejo et al. [30] in triplicate, where $90 \mathrm{mg}$ of lyophilised sample was weighed in tubes and mixed with $9 \mathrm{~mL}$ of hexane 
and $15 \mathrm{~mL}$ of a methanol/acetone dilution $(1: 2, v / v)$. The extraction was carried out in an orbital shaker, where the samples were vigorously shaken for $4 \mathrm{~h}$ in darkness at $4{ }^{\circ} \mathrm{C}$. After extraction, $25 \mathrm{~mL}$ of a $1 \mathrm{M} \mathrm{NaCl}$ solution was added, and the samples were shaken in a vortex. The absorbance was measured at $470 \mathrm{~nm}$ in quartz cells (Hellma GmbH\&Co., Müllheim, Germany) using a UV-visible spectrophotometer (Hewlett Packard, model 8453, Columbia, SC, USA). Three replicates were performed for each sample. The equations developed by Wellburn [31] were used to determine the total carotenoids content (TCC):

$$
\text { Carotenoids }\left(\mu \mathrm{g} \mathrm{mL}^{-1}\right)=\frac{\left(1000 \times A b s_{470}\right)-\left(1.28 \times C_{a}\right)-\left(56.7 \times C_{b}\right)}{205}
$$

Being:

$$
\begin{aligned}
& C_{a}\left(\mu \mathrm{g} \mathrm{mL}^{-1}\right)=\left(10.05 \times A b s_{662}\right)-\left(0.766 \times A b s_{644}\right) \\
& C_{b}\left(\mu \mathrm{g} \mathrm{mL}^{-1}\right)=\left(16.37 \times A b s_{644}\right)-\left(3.14 \times A b s_{662}\right)
\end{aligned}
$$

Values were expressed as $\mu \mathrm{g}$ carotenoid $\mathrm{g}^{-1} \mathrm{DW}$.

\subsection{Data Analysis}

The experiment was a two-factor design (UV-B dose $\times$ sampling time) subjected to two-way ANOVA using Statgraphics Centurion 19 software (Statpoint Technologies. Inc. The Plains, Warrenton, VA, USA). Hence, UV-B doses were: 0 (CTRL), 5 (T5), 10 (T10), and 15 (T15), and days of sampling time were: 0 (seed); 3, 5, 7 (sprouting days); 10/0 (harvesting); and $10+3,10+7,10+10$ (storage at $4{ }^{\circ} \mathrm{C}$ ). Statistical significance was assessed at the level $p<0.05$, and Tukey's multiple range test was used to separate means.

Changes in the total bioactive compound content and TAC were fitted to sigmoidal curves [32] with XLSTAT. The accumulation of bioactive compounds as a sigmoidal model has been previously described by Rogez et al. [33]: a phase of high growth is observed until reaching a plateau phase led by a maximum concentration. The fit converged for all datasets. Sigmoidal curves presented a plateau at $C_{M A X}$ (maximal concentration in red cabbage sprouts) and a variable slope factor $(g)$. All the obtained results fitted to the function:

$$
Y=\frac{C_{M A X}}{1+10^{\left(X_{1 / 2}-X\right) \times g}}
$$

where $Y$ was the concentration of the measured bioactive compound, $g$ was the gain term (Hill slope), and $X$ was the time (in days).

\section{Results}

\subsection{Morphological Parameters of Red Cabbage Sprouts}

The hypocotyl length of the 3-day sprouts grown in darkness (CTRL) was $0.25 \pm 0.12 \mathrm{~cm}$, while T10 treatment stimulated the growth by $82 \%$ (Table 1 ).

After 5 days, all UV treatments increased the hypocotyl length compared to CTRL samples by 51,88 , and $44 \%$ for $\mathrm{T} 5, \mathrm{~T} 10$, and $\mathrm{T} 15$, respectively, reporting $\mathrm{T} 10$ as the highest hypocotyl length. As shown in Table 1, UV-B-treated samples showed $75 \%$ higher hypocotyl length compared to CTRL samples on 10-day-old sprouts, but there were no differences among the UV treatments (T5, T10, and T15) on the same day of growth. As root growth was irregular (Figure 2), we measured the total sprout length (hypocotyl + root) after 5 and 7 days; the T10-treated red cabbage sprouts were $90 \%$ ( 5 days) and $44 \%$ ( 7 days) higher than CTRL. 
Table 1. Morphological characteristics of UV-B treated (0 -CTRL-, 5, 10, and $15 \mathrm{~kJ} \mathrm{~m}^{-2}$ ) red cabbage sprouts during 10 growing days at $20^{\circ} \mathrm{C}$.

\begin{tabular}{|c|c|c|c|c|c|c|}
\hline Days at $20^{\circ} \mathrm{C}$ & Treatment & $\begin{array}{l}\text { Hypocotyl Length } \\
\text { (cm) }\end{array}$ & $\begin{array}{l}\text { Sprout Length } \\
(\mathrm{cm})\end{array}$ & H/R Ratio & Moisture (\%) & $\begin{array}{l}\text { Growth Rate } \\
\left(m m \text { day }^{-1}\right) \text { * }\end{array}$ \\
\hline \multirow{4}{*}{3} & CTRL & $0.25 \pm 0.12^{\mathrm{B} \mathrm{d}}$ & $1.03 \pm 0.07^{c}$ & $0.35 \pm 0.21 \mathrm{AB} c$ & $61.8 \pm 0.3^{\mathrm{Bc}}$ & $0.82 \pm 0.40^{\mathrm{Bc}}$ \\
\hline & T5 & $0.27 \pm 0.07^{\mathrm{AB} \mathrm{d}}$ & $1.01 \pm 0.17^{\mathrm{c}}$ & $0.38 \pm 0.14^{\mathrm{AB} \mathrm{c}}$ & $59.9 \pm 1.7 \mathrm{~B} \mathrm{c}$ & $0.91 \pm 0.22 \mathrm{ABc}$ \\
\hline & $\mathrm{T} 10$ & $0.45 \pm 0.06^{\mathrm{Ac}}$ & $1.13 \pm 0.11^{\mathrm{c}}$ & $0.65 \pm 0.07 \mathrm{~A} \mathrm{~b}$ & $64.6 \pm 2.2^{\mathrm{Ac}}$ & $1.49 \pm 0.20 \mathrm{Ac}$ \\
\hline & $\mathrm{T} 15$ & $0.21 \pm 0.02{ }^{\mathrm{B} \mathrm{d}}$ & $0.96 \pm 0.15^{c}$ & $0.28 \pm 0.02^{\mathrm{Bc}}$ & $55.5 \pm 1.5^{\mathrm{Cd}}$ & $0.69 \pm 0.07^{\mathrm{B} \mathrm{c}}$ \\
\hline \multirow{4}{*}{5} & CTRL & $0.76 \pm 0.04^{C c}$ & $1.97 \pm 0.17^{\mathrm{Cb}}$ & $0.63 \pm 0.09^{b}$ & $63.5 \pm 1.5^{\mathrm{AB} \mathrm{c}}$ & $1.52 \pm 0.08^{\mathrm{Cb}}$ \\
\hline & $\mathrm{T} 5$ & $1.15 \pm 0.05^{\mathrm{B} \mathrm{c}}$ & $2.75 \pm 0.16^{\mathrm{B} \mathrm{b}}$ & $0.72 \pm 0.04^{b c}$ & $64.2 \pm 1.3^{\mathrm{Ac}}$ & $2.29 \pm 0.11^{\mathrm{B} \mathrm{b}}$ \\
\hline & $\mathrm{T} 10$ & $1.43 \pm 0.03^{\mathrm{A} \mathrm{b}}$ & $3.74 \pm 0.25 \mathrm{~A} \mathrm{~b}$ & $0.62 \pm 0.07^{b}$ & $61.3 \pm 0.1^{\mathrm{B} \mathrm{c}}$ & $2.85 \pm 0.07^{\mathrm{A} \mathrm{b}}$ \\
\hline & $\mathrm{T} 15$ & $1.09 \pm 0.09 \mathrm{~B} \mathrm{c}$ & $2.82 \pm 0.16^{\mathrm{B} \mathrm{b}}$ & $0.63 \pm 0.07^{b}$ & $60.3 \pm 1.9^{\mathrm{Bc}}$ & $2.18 \pm 0.19 \mathrm{~B} \mathrm{~b}$ \\
\hline \multirow{4}{*}{7} & CTRL & $1.69 \pm 0.05^{\mathrm{Db}}$ & $3.82 \pm 0.43^{\mathrm{B} \mathrm{a}}$ & $0.81 \pm 0.16^{b}$ & $67.6 \pm 4.0^{\mathrm{B} \mathrm{b}}$ & $2.41 \pm 0.07 \mathrm{D} \mathrm{a}$ \\
\hline & T5 & $2.20 \pm 0.14^{\mathrm{Cb}}$ & $5.06 \pm 0.74 \mathrm{AB} \mathrm{a}$ & $0.80 \pm 0.20^{b}$ & $75.6 \pm 2.5^{\mathrm{A} \mathrm{b}}$ & $3.14 \pm 0.20 \mathrm{Ca}$ \\
\hline & $\mathrm{T} 10$ & $3.17 \pm 0.11 \mathrm{~A} \mathrm{a}$ & $5.49 \pm 0.37 \mathrm{~A} \mathrm{a}$ & $1.39 \pm 0.21^{\mathrm{a}}$ & $78.2 \pm 4.3 \mathrm{~A} \mathrm{~b}$ & $4.53 \pm 0.15 \mathrm{~A} \mathrm{a}$ \\
\hline & T15 & $2.52 \pm 0.06^{\mathrm{B} \mathrm{b}}$ & $4.81 \pm 0.81 \mathrm{AB}$ a & $1.20 \pm 0.44^{\mathrm{a}}$ & $73.3 \pm 0.4^{\mathrm{AB} \mathrm{b}}$ & $3.60 \pm 0.09 \mathrm{~B} \mathrm{a}$ \\
\hline \multirow{4}{*}{10} & CTRL & $2.41 \pm 0.21^{\mathrm{B} \mathrm{a}}$ & $4.33 \pm 0.16^{\mathrm{a}}$ & $1.27 \pm 0.20^{\mathrm{a}}$ & $79.6 \pm 2.2^{\mathrm{B} \mathrm{a}}$ & $2.41 \pm 0.21^{\mathrm{B} \mathrm{a}}$ \\
\hline & T5 & $3.20 \pm 0.06^{\mathrm{A} \mathrm{a}}$ & $5.19 \pm 0.37^{\mathrm{a}}$ & $1.67 \pm 0.38^{\mathrm{a}}$ & $84.8 \pm 3.0^{\mathrm{A} \mathrm{a}}$ & $3.20 \pm 0.06^{\mathrm{A} \mathrm{a}}$ \\
\hline & $\mathrm{T} 10$ & $3.18 \pm 0.12 \mathrm{~A} \mathrm{a}$ & $5.07 \pm 0.61^{\mathrm{a}}$ & $1.77 \pm 0.45^{\mathrm{a}}$ & $85.6 \pm 3.1 \mathrm{~A} \mathrm{a}$ & $3.18 \pm 0.12 \mathrm{Ab}$ \\
\hline & $\mathrm{T} 15$ & $3.28 \pm 0.15^{\mathrm{A} \mathrm{a}}$ & $5.12 \pm 0.54^{\mathrm{a}}$ & $1.84 \pm 0.40^{\mathrm{a}}$ & $83.6 \pm 0.4 \mathrm{AB} \mathrm{a}$ & $3.28 \pm 0.15^{\mathrm{A} \mathrm{a}}$ \\
\hline
\end{tabular}

H/R: hypocotyl/root. FW/DW: fresh weight/dry weight. ${ }^{*}$ Growth rate was calculated by dividing the hypocotyl (mm) length by the days of growth. Different capital letters denote significant differences $(p<0.05)$ among different treatments for the same sampling time according to Tukey's test. Different lowercase letters denote significant differences $(p<0.05)$ among different sampling times for the same treatment according to Tukey's test.
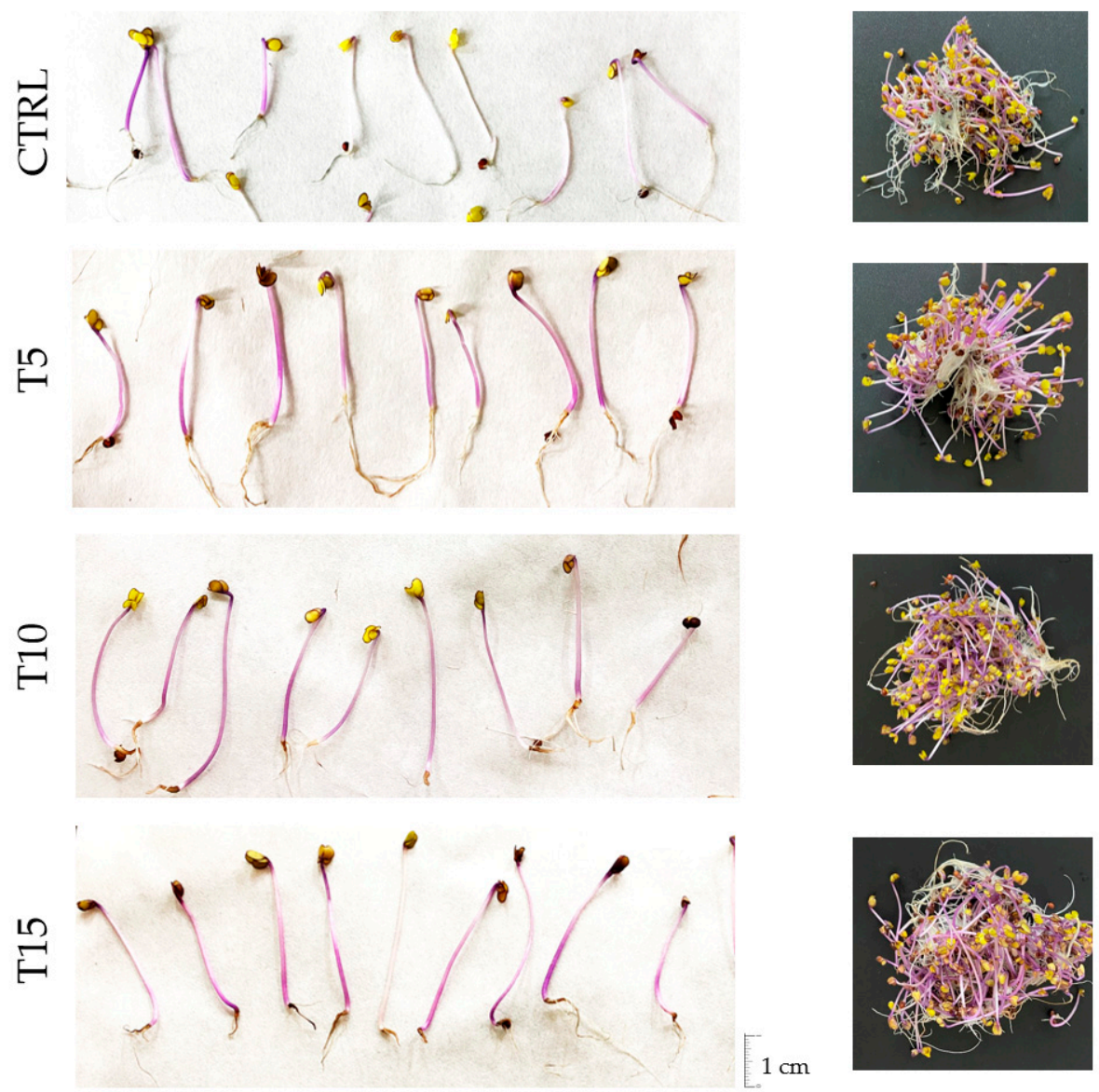

Figure 2. Representative pictures of control (0, CTRL) or UV-B-treated $\left(5,10\right.$, and $\left.15 \mathrm{~kJ} \mathrm{~m}^{-2}\right)$ red cabbage sprouts after 10 growing days at $20^{\circ} \mathrm{C}$ and $90 \% \mathrm{RH}$. 
The hypocotyl/root (H/R) ratio of 3-day sprouts was less than 1 for all treatments, being almost double in T10-treated samples than the remaining treatments because T10-treated sprouts had longer hypocotyls compared to the other treatment at the third sprouting day. From day 5 onwards, no differences were observed between UV-B and CTRL treatments. Furthermore, as the growth of the hypocotyl increased, the H/R ratio was higher than 1. The T10 treatment increased the growth speed of the 3-day sprouts to $1.49 \pm 0.20 \mathrm{~mm} \mathrm{day}^{-1}$ compared to CTRL sprouts $\left(0.82 \pm 0.40 \mathrm{~mm} \mathrm{day}^{-1}\right)$. The higher UV-B radiation applied $\left(15 \mathrm{~kJ} \mathrm{~m}^{-2}\right)$ slowed down the sprouts' growth speed after 3 days, although such a dose (T15) experienced a higher growth speed compared to the CTRL on the remaining application days. As expected, moisture (\%) increased as sprouts grew. Although no clear trend was observed in our experiment, it should be mentioned that T10 treatment reported on many occasions the highest values, which might be related to higher growth rate and sprout lengths in these sprouts.

\subsection{Bioactive Compounds}

\subsubsection{TPC}

The TPC increased by $148 \%$ after 10 days of sprouting, from $6.94 \pm 0.45 \mathrm{mg} \mathrm{CAE} \mathrm{g}^{-1} \mathrm{DW}$ (seed) to $17.21 \pm 0.41 \mathrm{mg} \mathrm{CAE} \mathrm{g}^{-1} \mathrm{DW}$ reported in CTRL samples (Figure 3). In the same way, the TPC increased by $35 \%$ during the post-harvest period, up to $23.21 \pm 0.84 \mathrm{mg} \mathrm{CAE} \mathrm{g}^{-1}$ DW observed in CTRL samples after 10 days at $4{ }^{\circ} \mathrm{C}$, which represented an increase of $234 \%$ throughout the study.

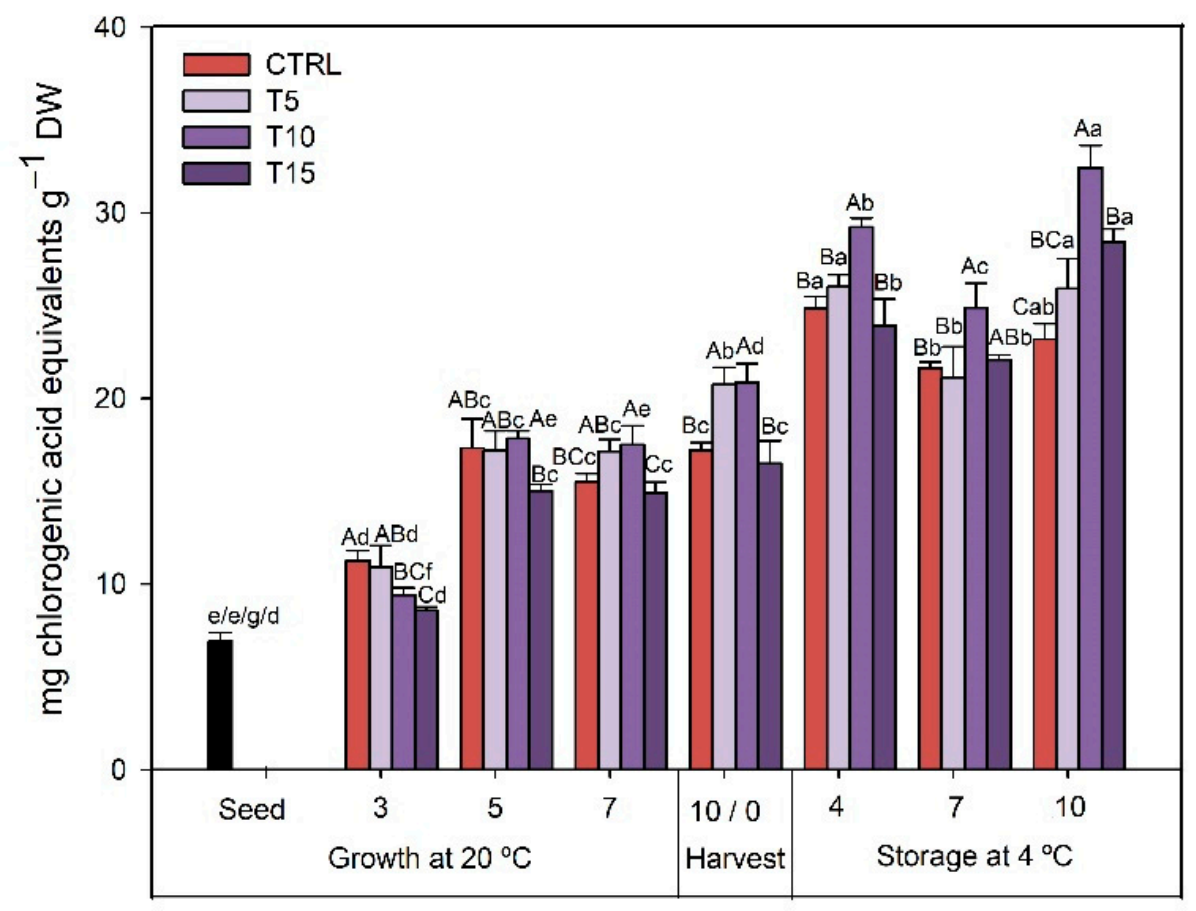

Figure 3. Total phenolic content of control (0, CTRL) or UV-B-treated $\left(5,10\right.$, and $\left.15 \mathrm{~kJ} \mathrm{~m}^{-2}\right)$ red cabbage sprouts after 10 days growth at $20^{\circ} \mathrm{C}$ and stored 10 days at $4{ }^{\circ} \mathrm{C}$ after harvest. Different capital letters indicate significant differences among treatments at $p<0.05$ according to Tukey's test ( $n=6$, which were the plates collected, and each plate is a repetition). Different lowercase letters indicate significant differences among time of analysis of the same treatment at $p<0.05$ according to Tukey's test.

The TPC changes followed a sigmoidal increase trend in all treatments $\left(R^{2}>0.900\right)$, with T5 being the one with the highest slope (0.111), followed by CTRL, T10, and T15 (Table 2), which means a faster increase in TPC in the T5 samples. The maximum TPC $\left(C_{M A X}\right)$ ranged from 24.9 to $72.1 \mathrm{mg} \mathrm{g}^{-1} \mathrm{DW}$, with $\mathrm{T} 15$ being the treatment that induced 
the higher TPC increase followed by T10 (Table 2) during germination at $20^{\circ} \mathrm{C}$. Therefore, T10-treated seedlings at the end of the study $\left(10\right.$ days at $\left.4^{\circ} \mathrm{C}\right)$ had 40,25 , and $14 \%$ more phenolic compounds compared to CTRL, T5, and T15 samples, respectively. In fact, T10 treatment showed the highest coefficient of determination in the regression predictions of a sigmoidal kinetic $\left(R^{2}=0.932\right)$, which makes this model reliable for predicting the quantity of TPC in red cabbage sprouts under the UV treatments.

Table 2. Mathematical description models for the biosynthesis of the main bioactive compounds content and for the total antioxidant capacity in UV-B-treated ( $(\mathrm{CTRL}), 5,10$, and $15 \mathrm{~kJ} \mathrm{~m}^{-2}$ ) red cabbage sprouts during 10 germination days at $20^{\circ} \mathrm{C}+10$ days at $4{ }^{\circ} \mathrm{C}$ as a minimally processed product.

\begin{tabular}{|c|c|c|c|c|c|}
\hline & Treatment & $C_{M A X}\left(\mathrm{mg} \mathrm{g}^{-1} \mathrm{DW}\right)$ & $\mathrm{X}_{1 / 2}$ & $\mathrm{~g}$ & $\mathbf{R}^{2}$ \\
\hline \multirow{4}{*}{$\begin{array}{l}\cup \\
E \\
E\end{array}$} & CTRL & 25.2 & -14.0 & 0.054 & 0.900 \\
\hline & $\mathrm{T} 5$ & 25.0 & 2.5 & 0.111 & 0.927 \\
\hline & T10 & 40.7 & -19.0 & 0.031 & 0.932 \\
\hline & $\mathrm{T} 15$ & 72.1 & -119.9 & 0.009 & 0.940 \\
\hline \multirow{4}{*}{$\underset{f}{\bigcup_{1}}$} & CTRL & 12.8 & 6.5 & 0.113 & 0.981 \\
\hline & T5 & 15.1 & 7.2 & 0.117 & 0.965 \\
\hline & T10 & 15.8 & 4.9 & 0.080 & 0.996 \\
\hline & $\mathrm{T} 15$ & 17.9 & 7.7 & 0.072 & 0.998 \\
\hline \multirow{4}{*}{$\underset{E}{U}$} & CTRL & $78.8 *$ & 9.0 & 0.323 & 0.937 \\
\hline & T5 & 111.8 * & 0.8 & 0.047 & 0.914 \\
\hline & T10 & 515.4 * & -65.6 & 0.006 & 0.962 \\
\hline & T15 & $105.9 *$ & 9.8 & 0.232 & 0.916 \\
\hline \multirow{4}{*}{ 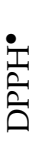 } & CTRL & 11.5 & 9.5 & 0.132 & 0.882 \\
\hline & T5 & 13.6 & 8.5 & 0.099 & 0.918 \\
\hline & T10 & 13.5 & 7.1 & 0.128 & 0.942 \\
\hline & T15 & 18.4 & 11.6 & 0.039 & 0.946 \\
\hline \multirow{4}{*}{ 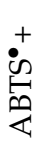 } & CTRL & 17.3 & -68.0 & 0.031 & 0.891 \\
\hline & T5 & 15.1 & -25.1 & 0.086 & 0.847 \\
\hline & T10 & 16.2 & -27.7 & 0.063 & 0.823 \\
\hline & T15 & 19.4 & -38.7 & 0.028 & 0.895 \\
\hline \multirow{4}{*}{$\frac{\mathbb{E}}{\frac{1}{L I}}$} & CTRL & 22.3 & -33.8 & 0.068 & 0.962 \\
\hline & $\mathrm{T} 5$ & 28.8 & 1.9 & 0.094 & 0.951 \\
\hline & T10 & 29.5 & 3.7 & 0.107 & 0.965 \\
\hline & T15 & 69.6 & -24.2 & 0.011 & 0.886 \\
\hline
\end{tabular}

* $\mu \mathrm{g} \mathrm{g}{ }^{-1}$ DW. TPC: total phenolic content; TFC: total flavonoid content; TCC: total carotenoid content.

\subsubsection{TFC}

Regarding the flavonoids (Figure 4), the TFC represents approximately half of the phenolic compounds (TPC) of red cabbage sprouts (Figure 5). Red cabbage seeds reported $3.72 \pm 0.09 \mathrm{mg}$ rutin per $\mathrm{g} \mathrm{DW}$, which increased in CTRL during the germination period from $55 \%$ on day 3 up to $150 \%$ after 10 days at $20{ }^{\circ} \mathrm{C}$. In the same way, after the post-harvest period of 10 days at $4{ }^{\circ} \mathrm{C}$, CTRL sprouts had an increased TFC to $12.01 \pm 0.47 \mathrm{mg}$ rutin per g DW, showing an increase up to $223 \%$ compared to the initial value. UV-B stimulated the biosynthesis of flavonoids, with the highest increase reported for T15 compared to CTRL samples (31\%; $15.69 \pm 0.48 \mathrm{mg}$ rutin per $\mathrm{g}$ DW), although T5 and T10 also showed 19 and $23 \%$ increase, respectively.

The flavonoid accumulation throughout the time can also be fitted to a sigmoidal curve with $\mathrm{R}^{2}>0.965$ for all treatments (Table 2), which makes this model predictable and reliable. The highest $C_{\text {MAX }}$ was $17.9 \mathrm{mg} \mathrm{g}^{-1} \mathrm{DW}$ for the T15 treatment, followed by T10 and T5 with 15.8 and $15.1 \mathrm{mg} \mathrm{g}^{-1} \mathrm{DW}$, respectively. The highest slope was observed for T5 with 0.117 but the half $C_{\text {MAX }}$ was reached by earlier by T10-treated seedlings (4.9 days). 


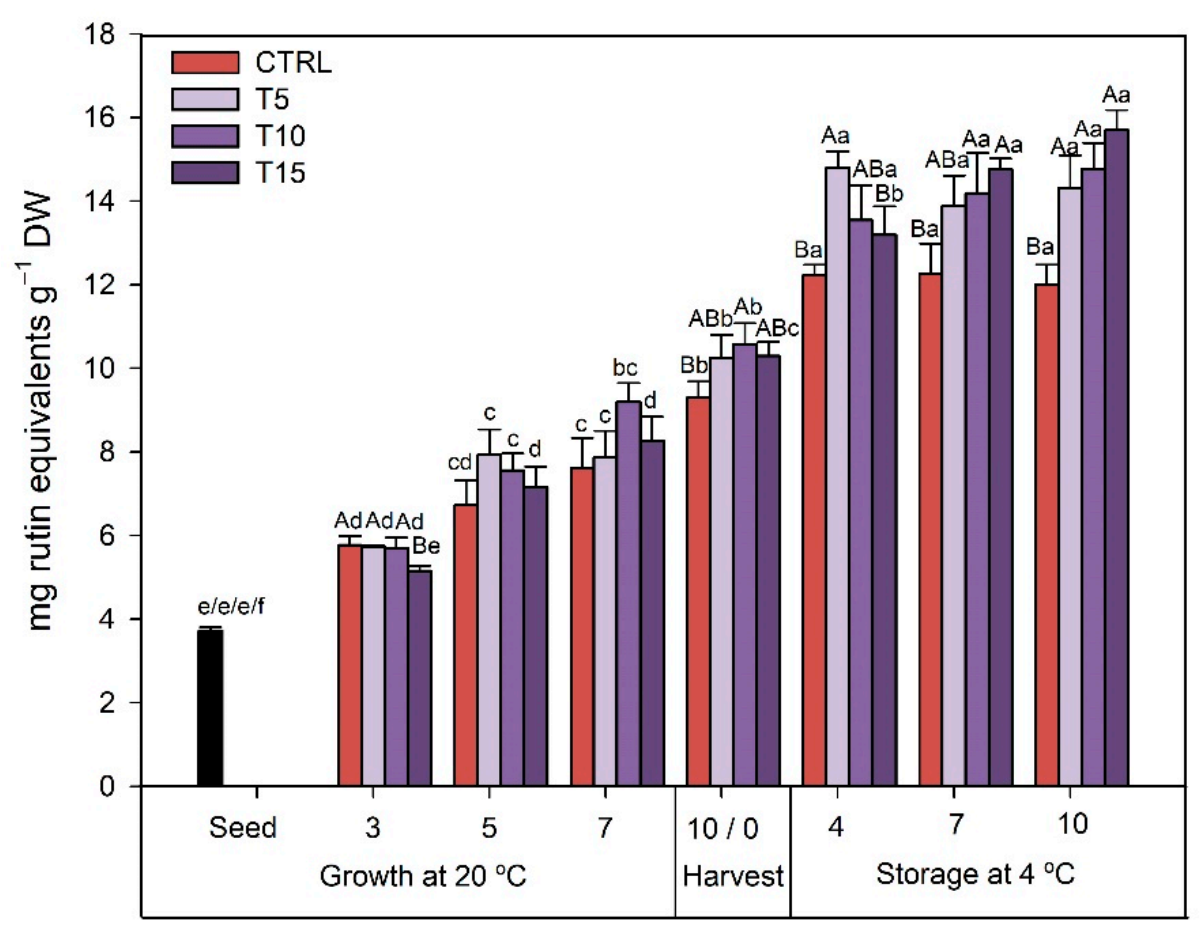

Figure 4. Total flavonoid content of control (0, CTRL) or UV-B treated $\left(5,10\right.$, and $\left.15 \mathrm{~kJ} \mathrm{~m}^{-2}\right)$ red cabbage sprouts after 10 days growth at $20^{\circ} \mathrm{C}$ and stored 10 days at $4{ }^{\circ} \mathrm{C}$ after harvest. Different capital letters indicate significant differences among treatments at $p<0.05$ according to Tukey's test ( $n=6$, which were the plates collected, and each plate is a repetition). Different lowercase letters indicate significant differences among time of analysis of the same treatment at $p<0.05$ according to Tukey's test.

\subsubsection{TAC}

The TAC was evaluated following three methods in which the scavenging activity against $\mathrm{DPPH}^{\bullet}$ and $\mathrm{ABTS}^{\bullet}+$ free radicals or the ability of our samples to reduce $\mathrm{Fe}^{+3}$ by FRAP was assessed. Obtained values by the $\mathrm{DPPH}^{\bullet}$ procedure are shown in Figure 5A, while Figure $5 \mathrm{~B}$ shows values by the $\mathrm{ABTS}^{\bullet}+$ assay and Figure $5 \mathrm{C}$ the TAC evaluated by the FRAP method. In fact, the antioxidant activity cannot be directly measured and it must be evaluated by several methods because antioxidant compounds act through several chemical mechanisms: free radical scavengers; singlet oxygen quenchers; inactivators of peroxides; and other ROS, metal ion chelators, quenchers of secondary oxidation products, and inhibitors of prooxidative enzymes [34,35].

The scavenging activity against $\mathrm{DPPH}^{\bullet}$ radical increased up to $24 \%$ throughout 10 days of germination in CTRL samples starting from $6.52 \pm 0.57 \mathrm{mg} \mathrm{TE} \mathrm{g}^{-1} \mathrm{DW}$ in seeds. A higher increase (37\%) was observed after the subsequent post-harvest storage of 10 day at $4{ }^{\circ} \mathrm{C}$ in CTRL samples, reporting values of $11.07 \pm 0.56 \mathrm{mg} \mathrm{TE} \mathrm{g}^{-1} \mathrm{DW}$. Moreover, UV-B-treated samples (T5, T10, and T15) showed the highest ability to scavenge $\mathrm{DPPH}^{\bullet}$ free radicals at the end of the refrigerated storage (Figure 5A). Although a sigmoidal trend was observed, UV-treated sprouts were the ones with the highest TAC content measured by $\mathrm{DPPH}^{\bullet}$ assay. The $C_{\mathrm{MAX}}$ for T5, T10, and T15 were $13.6,13.6$, and $18.4 \mathrm{mg} \mathrm{g}^{-1} \mathrm{DW}$, respectively, compared to CTRL (11.5 $\left.\mathrm{mg} \mathrm{g}^{-1} \mathrm{DW}\right)$. Moreover, CTRL and T10 increased TAC faster compared to the remaining treatments, presenting the highest slopes ( 0.132 and 0.128 , respectively), while T15 obtained the lowest slope (0.039) with a linear improvement in its antioxidant capacity in the pre- and the post-harvest periods. In this way, T10 and T15 showed the highest fit to a sigmoidal kinetic with $R^{2}$ of 0.942 and 0.946 , respectively, which demonstrates the reliability of this model for predicting the TAC (measured by several methods) in 10-day-old red cabbage sprouts under the UV-B doses evaluated. 
A

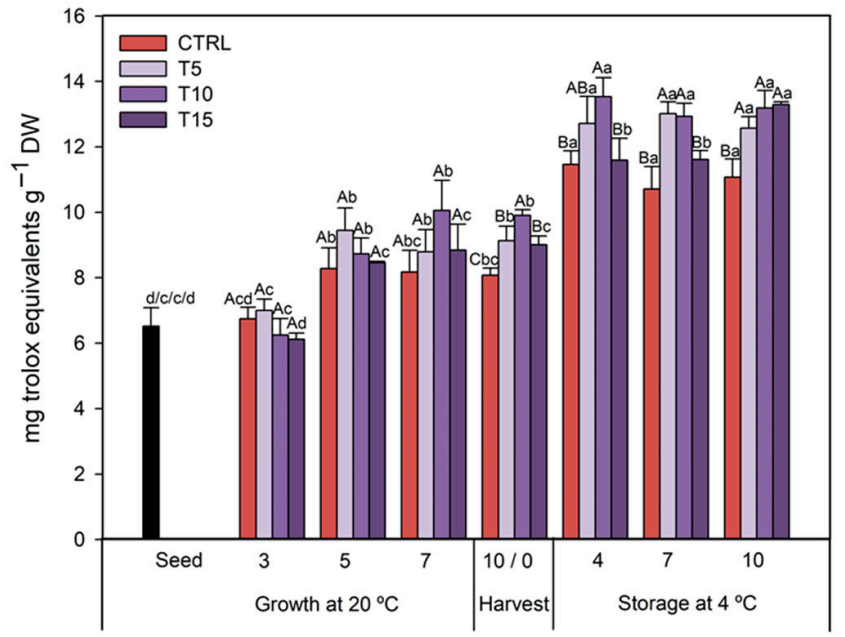

B

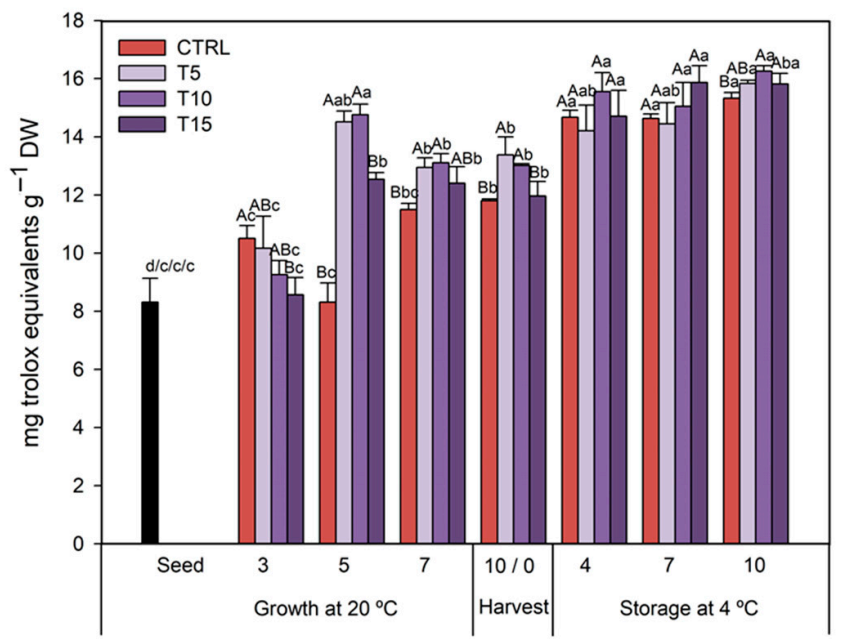

C

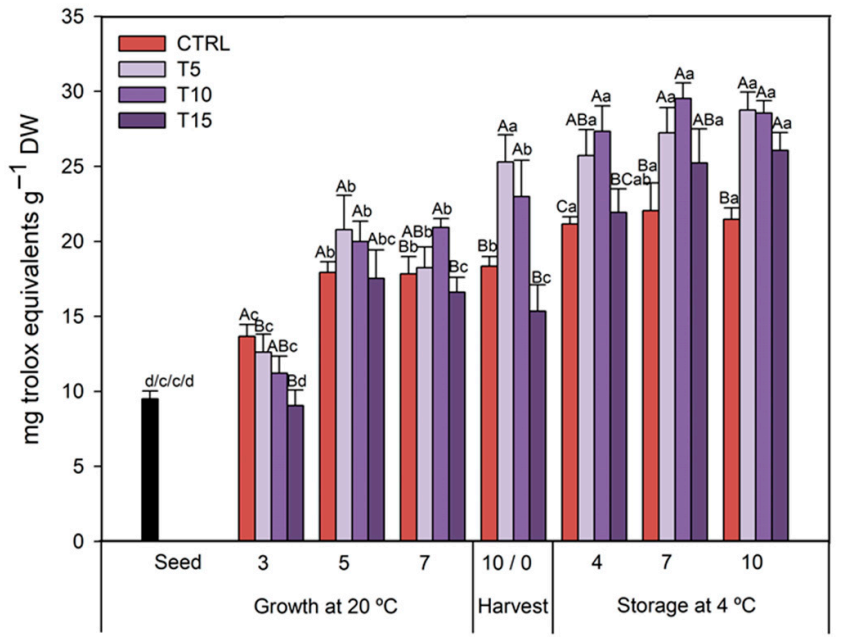

Figure 5. Total antioxidant capacity using the $\mathrm{DPPH}^{\bullet}(\mathbf{A}), \mathrm{ABTS}^{\bullet}+(\mathbf{B})$, and FRAP (C) methods of control (0, CTRL) or UV-B treated $\left(5,10\right.$, and $\left.15 \mathrm{~kJ} \mathrm{~m}^{-2}\right)$ red cabbage sprouts after 10 days growth at $20{ }^{\circ} \mathrm{C}$ and stored 10 days at $4{ }^{\circ} \mathrm{C}$ after harvest. Different capital letters indicate significant differences among treatments at $p<0.05$ according to Tukey's test $(n=6$, that were the plates collected, and each plate is a repetition). Different lowercase letters indicate significant differences among time of analysis of the same treatment at $p<0.05$ according to Tukey's test. 
The hydrophilic TAC evaluated by the $\mathrm{ABTS}^{\bullet}+$ method showed a similar behaviour to the lipophilic TAC registered by the DPPH${ }^{\bullet}$ assay, although higher values were reported (Figure 5B). Therefore, our sprouts were found to be slightly richer in hydrophilic antioxidants. Red cabbage seeds presented $8.31 \pm 0.82 \mathrm{mg} \mathrm{TE} \mathrm{g}^{-1} \mathrm{DW}$, which increased $42 \%$ after 10 pre-harvest day and up to $84 \%$ after the additional 10 days at $4{ }^{\circ} \mathrm{C}$ in CTRL samples. Nevertheless, no relevant differences were found in this case among CTRL and UV-B treatments throughout the post-harvest storage, although T5 and T10 were the most remarkable treatments, showing 1-2 $\mathrm{mg} \mathrm{TE}^{-1} \mathrm{DW}$ more than CTRL samples after 10 days of germination. Furthermore, the highest slope was reported for T5 (0.086), followed by T10 treatments (0.063), which means T5- and T10-treated seedlings increased their ability to scavenge $\mathrm{ABTS}^{\bullet}+$ free radical faster than the T15-treated or CTRL seedlings. The $C_{M A X}$ of the CTRL and UV-treated seedlings ranged from 15.1 to $19.4 \mathrm{mg} \mathrm{g}^{-1} \mathrm{DW}$ (Table 2).

When we used the FRAP assay, TAC increased importantly in UV-B-treated seedlings throughout the sprouting period (Figure 5C). Initially, red cabbage seeds reported $9.51 \pm 0.52 \mathrm{mg} \mathrm{TE} \mathrm{g}^{-1} \mathrm{DW}$, which increased in CTRL samples by 93 and $126 \%$ after 10 growing days at $20{ }^{\circ} \mathrm{C}$ and after the post-harvest storage of 10 days at $4{ }^{\circ} \mathrm{C}$, respectively. Moreover, after 10 days of sprouting, T5 and T10 showed 38 and 25\% higher TAC compared to CTRL samples, while T5-, T10-, and T15-treated seedlings had an improved TAC at the end of the study by 35, 33, and 21\%, respectively, compared to CTRL samples. In fact, although no great differences were shown among UV-B treatments after 7 or 10 days at $4^{\circ} \mathrm{C}$, T10-treated seedlings had a faster increase of TAC, measured by FRAP, than the seedlings treated with $\mathrm{T} 5$ or T15, which could be appreciated due to the higher slope (0.107) of the dose-dependence curve (Table 2).

From a general point of view, an increase of the TAC was observed during germination, which was accentuated during the post-harvest storage. However, a higher increase was detected in the UV-B-treated sprouts, with T10-treated seedlings having the highest TAC followed equally by T15 and T5. Furthermore, the sigmoidal increase of the TAC $\left(\mathrm{R}^{2}>0.88\right.$ for $\mathrm{DPPH}^{\bullet}$ and FRAP), with regards to the application of UV light under the described conditions, made it possible to model the TAC behaviour throughout the sprouting period or among the different UV-B doses applied.

\subsubsection{TCC}

The TCC of the red cabbage seeds was $12.53 \pm 1.56 \mu \mathrm{g}$ carotene $\mathrm{g}^{-1} \mathrm{DW}$. This concentration increased $3.5-\left(58.13 \pm 3.63 \mu \mathrm{g}\right.$ carotene $\left.\mathrm{g}^{-1} \mathrm{DW}\right)$ and 6.5 -fold $(81.31 \pm 1.44 \mu \mathrm{g}$ carotene $\mathrm{g}^{-1} \mathrm{DW}$ ) in CTRL sprouts after the growth and post-harvest periods, respectively (Figure 6). A periodical UV-B application of 10 and $15 \mathrm{~kJ} \mathrm{~m}^{-2}$ enhanced the biosynthesis of carotenoids by 36 and $32 \%$ after 10 days at $4{ }^{\circ} \mathrm{C}$ of post-harvest storage compared to CTRL samples, respectively. Moreover, the synthesis of carotenoids seemed to increase faster upon application of $15 \mathrm{~kJ} \mathrm{~m}^{-2}$ compared to the other UV-B doses, which could be appreciated by the slope (0.232) of the sigmoidal curve (Table 2). Therefore, this model also fitted a sigmoidal curve with a coefficient of determination higher than 0.914 , showing a great goodness of fit of the model prediction of the carotenoid content accumulation throughout time in red cabbage sprouts under the different UV-B treatments evaluated.

From a general point of view, carotenoids are the main bioactive compounds naturally increasing during sprout development. This natural increase was highly enhanced after low UV-B doses (T5). This increase was fitted to a linear model from the seed to the end of the sprouting period (harvest time). The UV-B doses applied during the sprouting period also reported effects during the refrigerated period after 4 days, when the phytochemicals naturally reached their maximum concentration $\left(C_{M A X}\right)$, and which was specially enhanced after T15 treatment. Moreover, such higher values were kept constant until the end of the shelf-life study. Therefore, a sigmoidal curve was the statistical model that better fitted to the biosynthesis of carotenoids during the whole study (sprouting + postharvest period). 


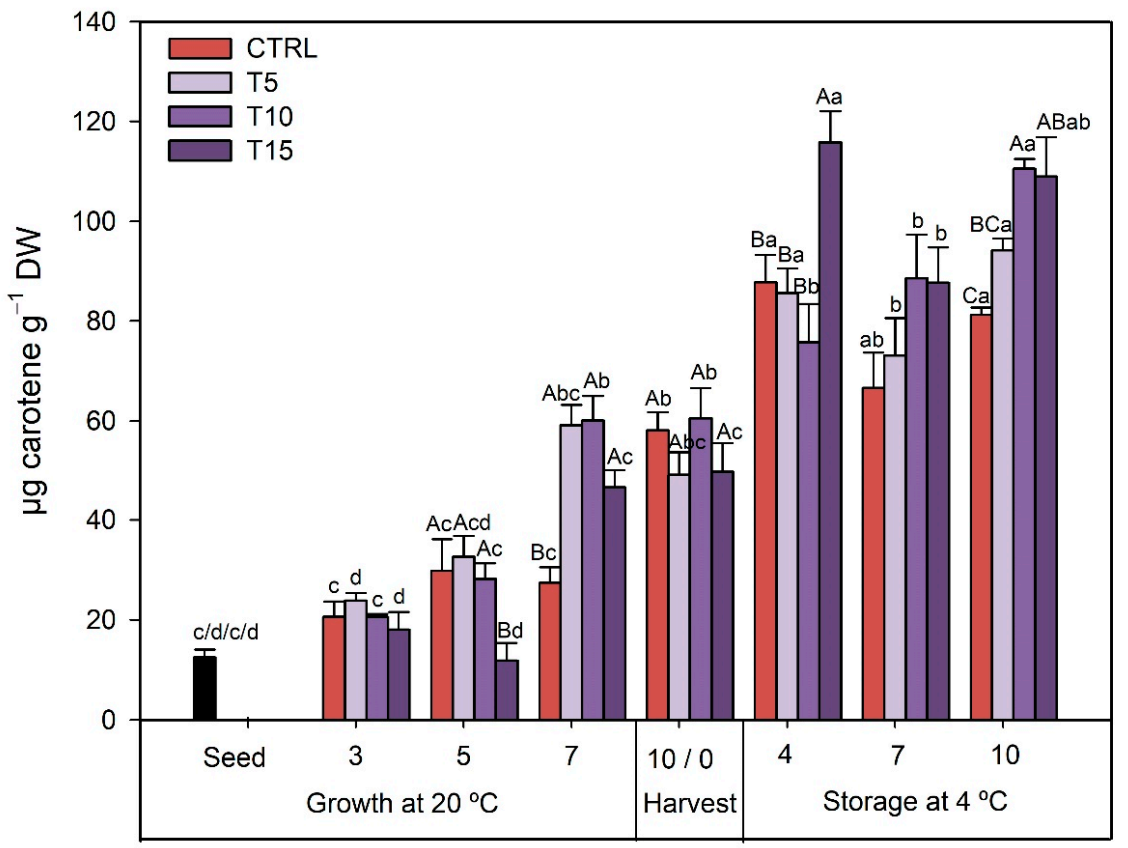

Figure 6. Total carotenoid content of control (0, CTRL) or UV-B treated $\left(5,10\right.$, and $\left.15 \mathrm{~kJ} \mathrm{~m}^{-2}\right)$ red cabbage sprouts after 10 days growth at $20^{\circ} \mathrm{C}$ and stored 10 days at $4{ }^{\circ} \mathrm{C}$ after harvest. Different capital letters indicate significant differences among treatments at $p<0.05$ according to Tukey's test ( $n=6$, that were the plates collected, and each plate is a repetition). Different lowercase letters indicate significant differences among time of analysis of the same treatment at $p<0.05$ according to Tukey's test.

\section{Discussion}

\subsection{UV-B Treatment Improved the Morphological Development of Sprouts}

In our study, the development of red cabbage was improved under UV-B treatments, especially after $10 \mathrm{~kJ} \mathrm{~m}^{-2}$ (T10) (Figure 1, Table 1), which can be explained by the photomorphogenic responses produced by young plants under such abiotic stress. In fact, a positive dose-response was observed from 0 (CTRL) to $10 \mathrm{~kJ} \mathrm{~m}^{-2}$ (T10), while higher doses (T15) did not show this improvement compared to untreated red cabbage sprouts (Table 1). A periodical UV-B illumination during germination favoured the growth of the hypocotyl length compared to CTRL. Similarly, Kacharava et al. [36] reported an increase in the height of 2 months white cabbage whose seeds were treated with $9 \mathrm{~kJ} \mathrm{~m}^{-2} \mathrm{UV}-\mathrm{B}$.

Mature plants under UV-B conditions trigger complex signal systems linking several types of photoreceptors that, in turn, trigger specific photomorphogenic responses such as changes in morphology, physiology, and production of secondary metabolites that can act as UV-absorbing screens [37]. UVR8 has been identified as a specific UV-B receptor, and the main proteins modulated by the UV-B photomorphogenic responses are COP1 and HY5 [38]. Indeed, the UVR8 receptors form a complex with COP1 and HY5, which triggers the expression of a set of genes involved in the plant acclimation response to UV-B.

As previously reviewed by Jansen and Bornman [15], low UV-B doses accelerated the binding between UVR8 and COP1, which activates the gene expression of HY5, directly associated with the phenylpropanoid pathway, and hence to the plant physiology and morphology [16]. Such authors also showed that Arabidopsis thaliana plants had an altered morphogenic response (decrease of $23 \%$ of the plant length) when treated with UV-B $\left(0.56 \mathrm{~kJ} \mathrm{~m}^{-2}\right.$ day $\left.^{-1}\right)$ in comparison with untreated UV-B plants.

By contrast, Zuk-Golaszewska et al. [39] showed that UV-B $\left(4,8\right.$, and $\left.12 \mathrm{~kJ} \mathrm{~m}^{-2} \mathrm{day}^{-1}\right)$ had no effect (i.e., no decrease of plant length) on Avenua fatua and Setaria viridis, which demonstrated again that plant response to UV-B is different depending the plant species and the UV dose tested. 
However, not all plant species have a stimulated growth by UV-B; some plant species are unaffected [40] or even had a plant growth inhibition [41-43]. The role of all actors involved in the UV-B response network remains unclear, possibly because many genetic changes do not lead to severe phenotypic variations [38]. Furthermore, several environmental factors such as light quantity and quality, increased temperature, or drought stress can increase the adaptation of plants to UV-B radiation [37]. For these reasons, the increase of temperature during the UV-B treatment (approximately $2{ }^{\circ} \mathrm{C}$ ) may explain the results obtained in the present study, but further research is needed to rule out this possibility.

\subsection{UV-B Treatment Enhanced the Biosynthesis of Nutraceuticals}

Although UV-B radiation may cause damage to plant tissues, an optimum dose can promote the accumulation of antioxidant and UV-protective molecules that enhance nutraceutical biosynthesis in plant foods without altering the sensory quality [11]. Such an increase in the concentration of bioactive compounds is mainly due to the environmental stress generated by UV-B light, which leads to changes in morphology, physiology, and the molecular conformation of DNA, RNA, and proteins.

One of the nutraceuticals we examined was the phenolic content by the Folin-Ciocalteu method (Figure 3). The measurement of TPC can be altered by the presence of some interfering substances, particularly sugars, aromatic amines, sulphur dioxide, ascorbic acid, organic acids, and Fe(II) [44]. For that, we corrected for interfering substances and used gallic acid as a reference standard. In our case, red cabbage is rich in vitamin $\mathrm{C}$ $\left(7.959 \pm 0.516 \mathrm{mg} \mathrm{g}^{-1} \mathrm{DW}\right)$ [45], which may interfere with Folin-Ciocalteu absorbances. Our results indicate an increase from $23.21 \pm 0.84 \mathrm{mg} \mathrm{CAE} \mathrm{g}^{-1} \mathrm{DW}$ in 10 days red cabbage sprouts (at harvest) to $32.42 \pm 1.20 \mathrm{mg} \mathrm{CAE} \mathrm{g}^{-1} \mathrm{DW}$ after 10 days of refrigerated storage. The phenolic content measured here is very similar to what Drozdowska et al. [45] obtained with HPLC (32.015 $\pm 0.516 \mathrm{mg}$ phenolic compounds $\mathrm{g}^{-1}$ DW in 14 days red cabbage sprouts). In addition, it should be noted that the comparative standard of gallic acid was not used in our present study, since the concentration of this phenolic acid is three times lower than chlorogenic acid content [45] in Brassicaceae sprouts. Therefore, our obtained values using chlorogenic acid instead of gallic acid as standard can make our obtained values more accurate, repeatable, and predictable.

Furthermore, our TPC results agree with those reported in "baby type" chard cultivated on hydroponic soil with different UV-B doses $\left(0,11,19\right.$, and $\left.29 \mathrm{~kJ} \mathrm{~m}^{-2}\right)$ in cycles of $3 \mathrm{~h} \mathrm{day}^{-1}$ over 8 days [46]. Their results showed an increase of 59 and $54 \%$ of the TPC compared to untreated plants, which demonstrated a quick protective response against adverse environmental conditions such as the presence of higher levels of UV-B radiation. The ability of the plants to produce higher levels of TPC when exposed to a continuous stress factor (here UV-B radiation) help them to become more resistant to future exposure [47]. Similarly, Formica-Oliveira et al. [21] analysed the effects of the combination of UV-B $\left(1.5 \mathrm{~kJ} \mathrm{~m}^{-2}\right)$ and $\mathrm{UV}-\mathrm{C}\left(4 \mathrm{~kJ} \mathrm{~m}^{-2}\right)$ on the biosynthesis of phenolic compounds in fresh-cut carrots. Freshly cut and grated carrots treated with UV-B $\left(1.5 \mathrm{~kJ} \mathrm{~m}^{-2}\right)$ achieved an accumulation of phenolic compounds of approximately $500 \%$ after $72 \mathrm{~h}$ at $15^{\circ} \mathrm{C}$, while non-UV-radiated samples showed an accumulation of $380 \%$ compared to their initial content.

The second nutraceutical measured in our study was the flavonoids, whose content is also highly correlated with TAC $\left(R^{2}>0.900\right)$. Flavonoids have received considerable attention because of their benefits for human health, as they are effective as cardio-protectors, antioxidants, anticarcinogens, anti-inflammatory agents, and antibacterial agents [11]. UVB lighting greatly affects flavonoid pathways and transforms the flavonoid's profile of several plants [48]. This was also the case in our study, when UV-B stimulated the biosynthesis of flavonoids in T15, T10, and T5 compared to CTRL samples by 31, 23, and 19\%, respectively. The flavonoid content in our study was measured following the aluminium chloride colorimetric method described by Hamed et al. [27] (Figure 5). It must be taken into account that aluminium chloride forms acid-stable complexes with the $\mathrm{C}-4$ keto group and either the C-3 or C-5 hydroxyl group of flavones and flavonols (kaempferol, rutin, 
quercetin, and myricetin), which had a maximum absorbance at $415 \mathrm{~nm}$ [49]. Considering that catechin and epicatechin are the major flavonoids found in red cabbage sprouts, representing $65 \%$ of the TFC [45], these compounds have their maximum absorbance at $280 \mathrm{~nm}$. For that, and according to our method, in the present study, rutin was chosen as standard to quantify the TFC $\left(\mathrm{R}^{2}=0.99\right)$, which had maximum absorbance at $415 \mathrm{~nm}$ [49].

Independently of the measurement method chosen, the effects of UV-B radiation on secondary metabolites are highly dose-dependent. In fact, biosynthesis and accumulation of flavonoids in chloroplasts, vacuoles, and plant cell walls are largely controlled by the intensity and exposure to UV-B radiation [48]. In general, our results, previously described, agree with the fact that higher UV-B radiation doses tend to trigger flavonoid accumulation in plants. For instance, Hectors et al. [16] showed increases in the concentrations of kaempferol derivatives from 2.1- to 19-fold in Arabidopsis thaliana under $0.56 \mathrm{~kJ} \mathrm{~m}^{-2}$ day $^{-1} \mathrm{UV}-\mathrm{B}$ compared to CTRL. Moreover, Neugart et al. [50] showed that UV-B $\left(0.22-0.88 \mathrm{~kJ} \mathrm{~m}^{-2}\right.$ day $\left.^{-1}\right)$ induced remarkable increases (even fivefold higher) in kaempferol and hydroxycinnamic acid derivatives in a dose-dependent manner during sprouting of kale (Brassica oleracea var. sabellica). Furthermore, recently Neugart et al. [51] have shown that Arabidopsis thaliana under UV-B treatments (from $2.376 \mathrm{~kJ} \mathrm{~m}^{-2}$ to $9.072 \mathrm{~J} \mathrm{~m}^{-2}$ ) can trigger the biosynthesis of kaempferol glycosides to contribute to the adaptation to UV radiation. In this sense, and regarding previous findings, TFC results in the present study can be justified in relation to the biosynthesis of flavonoids, especially rutin and kaempferol derivatives, as main flavonoids identified in Brassicaceae family.

Topcu et al. [52] evaluated the effect of different UV-B doses (2.2, 8.8, and $16.4 \mathrm{~kJ} \mathrm{~m}^{-2} \mathrm{~d}^{-1}$ ) on broccoli florets, and they found that TPC and TFC increased by 64 and $82 \%$, respectively, after $8.8 \mathrm{~kJ} \mathrm{~m}^{-2}$ day $^{-1} \mathrm{UV}-\mathrm{B}$ illumination compared to CTRL. Such increases in the TFC are a response of the plants' secondary metabolism as a result against the abiotic stress applied by the UV radiation, similarly to the results obtained in our study. Plants have a high capacity to respond to UV-B exposure. Plants possess five different types of sensory photoreceptors that allow them to accurately perceive ambient light and generate the responses to prevent damage and enhance photosynthesis. UVR8 is the most widely reported UV-B photoreceptor, regulating a wide range of UV-B responses, including flavonoid biosynthesis, hypocotyl growth inhibition, leaf cell expansion [13], protection against oxidative stress, and DNA repair [53]. Besides UV photoreceptors, which seem to be activated at low doses, the beneficial responses to stimulate the biosynthesis of phytochemicals, as secondary metabolites, are also mediated by ROS. In this sense, the accumulation rate of antioxidants does not seem to decrease when the sprouts are cooled from 20 to $4{ }^{\circ} \mathrm{C}$ at least in the initial 4 days, which suggests that the biosynthetic route for the most strongly induced antioxidants is not highly temperature-dependent in this range. It may be possible that low temperature stress, combined with low UV-B doses, could act as an inductor of the bioactive compound's synthesis [14].

In fact, this increase in phenolic compound content is directly related to the antioxidant capacity $\left(\mathrm{R}^{2}>0.900\right.$; TAC measured by DPPH ${ }^{\bullet}$ (Figure $\left.5 \mathrm{~A}\right) ; \mathrm{ABTS}^{\bullet}+($ Figure $5 \mathrm{~B})$; and FRAP (Figure 5C)). These increases were also observed in 6-day-old buckwheat sprouts (Fagopyrum esculentum Moench) under darkness conditions with different sources of visible and UV light (at different wavelengths: $260-320 \mathrm{~nm}, 280-320 \mathrm{~nm}$, and 300-320 nm) with a dose of $10 \mu \mathrm{mol} \mathrm{m}{ }^{-2} \mathrm{~s}^{-1}$ PPFD. The TAC measured by DPPH ${ }^{\bullet}$ (Figure 5A) was higher in UV-B-irradiated sprouts $\left(25.3 \mathrm{mmol} \mathrm{TE} 100 \mathrm{~g}^{-1} \mathrm{DW}\right)$. The results showed that a radiation with UV-B > $300 \mathrm{~nm}$ at a PPFD dose of $10 \mu \mathrm{mol} \mathrm{m} \mathrm{m}^{-2} \mathrm{~s}^{-1}$ increased the TAC by 1.6-fold compared to the sprouts kept in darkness. Moreover, the TAC was higher in the postharvested seedlings compared to seedlings at germination phase. Darré et al. [14] evaluated the UV-B dose-dependence effect between colour retention and TAC of broccoli florets (B. oleracea var. italica). As a result, samples exposed to $2 \mathrm{~kJ} \mathrm{~m}^{-2} \mathrm{UV}-\mathrm{B}$ showed an increase in TAC 6 and $18 \mathrm{~h}$ after the UV treatment in comparison with initial values at harvest. These data agree with the results obtained in our work. The TAC accumulation mainly 
resulted from the accumulation of phenolic compounds, but it is known that the responses to UV exposure depend on the ontogenetic stage of the fruit. Several works have suggested that abiotic stresses induced by UV-B radiation could be a valuable technological strategy to increase the TAC of fresh processed sprouts [11]. However, the responses reported in the literature are very variable depending on the product and the treatment applied. Csepregi et al. [48] evaluated the effect of UV-B on TAC and the flavonols accumulation in Arabidopsis leaves. Leaves exposed to UV-B radiation of $0.6648 \mathrm{~kJ} \mathrm{~m}^{-2}$ day $^{-1}$ for 7 days at $22{ }^{\circ} \mathrm{C}$ showed higher TAC values.

The last nutraceutical measured was the carotenoid, whose content is also related to the antioxidant activity in plants, and previous authors have already shown that UV-B is able to increase the concentration in these secondary metabolites. Red cabbage adult plants are naturally rich in carotenoid compounds, especially in carotenes ( $\beta$-carotene) and xanthophylls (lutein) [54,55], which have their maximum absorbance at 456 and $465 \mathrm{~nm}$, respectively, making them measurable at $470 \mathrm{~nm}$ [31]. He et al. [56] investigated the effects of UV-B radiation and $\mathrm{CaCl}_{2}$ on the improvement of the carotenoid content in maize kernel sprouts. A UV-B radiation of $0.375 \mu \mathrm{W} \mathrm{m}^{-2}$ applied in $1 \mathrm{~h}\left(0.0324 \mathrm{~kJ} \mathrm{~m}^{-2}\right.$ day $\left.^{-1}\right)$ increased the content of the six predominant carotenoids found compared to untreated control. This reveals that UV-B radiation can increase the carotenoid content and the activity of the antioxidant enzyme. In addition, $\mathrm{CaCl}_{2}$ may further improve carotenoid content and reduce photooxidative damages caused by UV-B radiation. Our hypothesis to explain this increase in the carotenoid concentration in red cabbage sprouts is based on the improvement of the biosynthesis of carotenes under UV-B radiation. In this sense, UVR8, as main UV-B receptors, are in charge to activate several transcription factors, such as COP1 (linked to HY5), as main stimulator of the PHYTOENE SYNTHASE (PSY), the first enzyme of carotenogenesis $[13,57,58]$. This behaviour has been recently shown in red peppers after a UV-B dose of $6 \mathrm{~kJ} \mathrm{~m}^{-2}$ applied before a short retailing period, which increased by $20 \%$ the carotenoid accumulation, especially in combination with a blue + red LED photoperiod during the nights at supermarkets [59].

\section{Conclusions}

Periodical UV-B pulses at low doses improved the morphological development of red cabbage sprouts and probably will have the same effect on other sprouts. Similarly, TPC, TFC, and TAC presented a UV-B dose-dependence response. Indeed, the TPC increased in UV-B-treated sprouts throughout the study, reaching the highest content with the application of $10 \mathrm{~kJ} \mathrm{~m}^{-2}$ UV-B during growing (T10). Furthermore, TFC and TAC were also gradually enhanced in T10-treated samples, reaching around 30\% higher content than in CTRL samples. Similarly, the biosynthesis of carotenoids was also improved under UV-B radiation, this time being $15 \mathrm{~kJ} \mathrm{~m}^{-2} \mathrm{UV}-\mathrm{B}$, the treatment that obtained the best results. Therefore, our results demonstrated that the application of UV-B light during germination induces a positive effect on the growth of red cabbage sprouts, as well as on the secondary metabolite content, which were related to the nutritional quality. The analysed bioactive compounds (phenolics, flavonoids, and carotenoids) increased during germination and tended to remain constant throughout a refrigerated shelf life. In particular, the total dose of $10 \mathrm{~kJ} \mathrm{~m}^{-2}$ proportionally applied on days 3, 5, 7, and 10 during germination is recommended. In future studies, the key will be to find an optimised UV-B dose for each species to enhance the phytochemical content without compromising the sensory quality of the treated products.

Supplementary Materials: The following are available online at https://www.mdpi.com/article/ 10.3390/horticulturae7120567/s1, Figure S1: UV-B ( $\lambda$ 280-315 nm) spectrum, peak in $294 \mathrm{~nm}$, provided by UV-B unfiltered emitting lamps (TL 40W/01 RS; Philips, Eindhoven, The Netherlands). Data provided by the supplier.

Author Contributions: Conceptualisation, F.A.-H.; methodology, L.M.-Z. and N.C.; software, L.M.-Z. and N.C.; validation, F.A.-H., L.M.-Z. and N.C.; formal analysis, F.A.-H.; investigation, F.A.-H., L.M.-Z. 
and N.C.; resources, F.A.-H.; data curation, L.M.-Z. and N.C.; writing-original draft preparation, F.A.-H., L.M.-Z. and N.C.; writing-review and editing, F.A.-H.; visualisation, F.A.-H. and L.M.-Z.; supervision, F.A.-H.; project administration, F.A.-H.; funding acquisition, F.A.-H. All authors have read and agreed to the published version of the manuscript.

Funding: This research was funded by the Autonomous Community of the Region of Murcia, grant number 20849/PI/18, through the grant call for projects for the development of scientific and technical research by competitive groups, included in the Regional Programme for the Promotion of Scientific and Technical Research (Action Plan 2018) of the Seneca Foundation-Science and Technology Agency of the Region of Murcia (Spain). Lorena Martínez-Zamora contract has been co-financed by the European Social Fund (ESF) and the Youth European Initiative (YEI) under the Spanish Seneca Foundation (21322/PDGI/19). Noelia Castillejo was funded by a predoctoral grant (FPU16/04763) from the Spanish Ministry of Education.

Institutional Review Board Statement: Not applicable.

Informed Consent Statement: Not applicable.

Data Availability Statement: Data sharing is not applicable to this article as all new created data are already contained within this article.

Acknowledgments: The technical assistance of Maria Teresa Jódar and Francisca Flores is highly appreciated.

Conflicts of Interest: The authors declare no conflict of interest.

\section{References}

1. Benincasa, P.; Falcinelli, B.; Lutts, S.; Stagnari, F.; Galieni, A. Sprouted grains: A comprehensive review. Nutrients 2019, $11,421$. [CrossRef] [PubMed]

2. Artés-Hernández, F.; Castillejo, N.; Martínez-Zamora, L.; Martínez-Hernández, G.B. Phytochemical Fortification in Fruit and Vegetable Beverages with Green Technologies. Foods 2021, 10, 2534. [CrossRef] [PubMed]

3. Raiola, A.; Errico, A.; Petruk, G.; Monti, D.M.; Barone, A.; Rigano, M.M. Bioactive compounds in brassicaceae vegetables with a role in the prevention of chronic diseases. Molecules 2018, 23, 15. [CrossRef] [PubMed]

4. Barba, F.J.; Mariutti, L.R.B.; Bragagnolo, N.; Mercadante, A.Z.; Barbosa-Cánovas, G.V.; Orlien, V. Bioaccessibility of bioactive compounds from fruits and vegetables after thermal and nonthermal processing. Trends Food Sci. Technol. 2017, 67, 195-206. [CrossRef]

5. Marton, M.; Mandoki, Z.S.; Csapo-Kiss, Z.S.; Csapo, J. The role of sprouts in human nutrition: A review. Acta Univ. Sapientiae 2010, 3, 81-117.

6. Šamec, D.; Pavlović, I.; Radojčić Redovniković, I.; Salopek-Sondi, B. Comparative analysis of phytochemicals and activity of endogenous enzymes associated with their stability, bioavailability and food quality in five Brassicaceae sprouts. Food Chem. 2018, 269, 96-102. [CrossRef]

7. Huché-Thélier, L.; Crespel, L.; Le Gourrierec, J.; Morel, P.; Sakr, S.; Leduc, N. Light signaling and plant responses to blue and UV radiations-Perspectives for applications in horticulture. Environ. Exp. Bot. 2016, 121, 22-38. [CrossRef]

8. Taulavuori, K.; Pyysalo, A.; Taulavuori, E.; Julkunen-Tiitto, R. Responses of phenolic acid and flavonoid synthesis to blue and blue-violet light depends on plant species. Environ. Exp. Bot. 2018, 150, 183-187. [CrossRef]

9. Klem, K.; Ač, A.; Holub, P.; Kováč, D.; Špunda, V.; Robson, T.M.; Urban, O. Interactive effects of PAR and UV radiation on the physiology, morphology and leaf optical properties of two barley varieties. Environ. Exp. Bot. 2012, 75, 52-64. [CrossRef]

10. Klem, K.; Holub, P.; Štroch, M.; Nezval, J.; Špunda, V.; Tříska, J.; Jansen, M.A.K.; Robson, T.M.; Urban, O. Ultraviolet and photosynthetically active radiation can both induce photoprotective capacity allowing barley to overcome high radiation stress. Plant Physiol. Biochem. 2015, 93, 74-83. [CrossRef]

11. Moreira-Rodríguez, M.; Nair, V.; Benavides, J.; Cisneros-Zevallos, L.; Jacobo-Velázquez, D.A. UVA, UVB light, and methyl jasmonate, alone or combined, redirect the biosynthesis of glucosinolates, phenolics, carotenoids, and chlorophylls in broccoli sprouts. Int. J. Mol. Sci. 2017, 18, 2330. [CrossRef]

12. Jenkins, G.I. Signal transduction in responses to UV-B radiation. Annu. Rev. Plant Biol. 2009, 60, 407-431. [CrossRef]

13. Jenkins, G.I. The UV-B photoreceptor UVR8: From structure to physiology. Plant Cell 2014, 26, 21-37. [CrossRef]

14. Darré, M.; Valerga, L.; Ortiz Araque, L.C.; Lemoine, M.L.; Demkura, P.V.; Vicente, A.R.; Concellón, A. Role of UV-B irradiation dose and intensity on color retention and antioxidant elicitation in broccoli florets (Brassica oleracea var. Italica). Postharvest Biol. Technol. 2017, 128, 76-82. [CrossRef]

15. Jansen, M.A.K.; Bornman, J.F. UV-B radiation: From generic stressor to specific regulator. Physiol. Plant. 2012, 145, 501-504. [CrossRef] 
16. Hectors, K.; Van Oevelen, S.; Guisez, Y.; Prinsen, E.; Jansen, M.A.K. The phytohormone auxin is a component of the regulatory system that controls UV-mediated accumulation of flavonoids and UV-induced morphogenesis. Physiol. Plant. 2012, 145, 594-603. [CrossRef]

17. Roeber, V.M.; Bajaj, I.; Rohde, M.; Schmülling, T.; Cortleven, A. Light acts as a stressor and influences abiotic and biotic stress responses in plants. Plant Cell Environ. 2021, 44, 645-664. [CrossRef]

18. Formica-Oliveira, A.C.; Martínez-Hernández, G.B.; Díaz-López, V.; Artés, F.; Artés-Hernández, F. Use of postharvest UV-B and UV-C radiation treatments to revalorize broccoli byproducts and edible florets. Innov. Food Sci. Emerg. Technol. 2017, 43, 77-83. [CrossRef]

19. Topcu, Y.; Dogan, A.; Kasimoglu, Z.; Sahin-Nadeem, H.; Polat, E.; Erkan, M. The effects of UV radiation during the vegetative period on antioxidant compounds and postharvest quality of broccoli (Brassica oleracea L.). Plant Physiol. Biochem. 2015, 93, 56-65. [CrossRef]

20. Formica-Oliveira, A.C.; Martínez-Hernández, G.B.; Díaz-López, V.; Artés, F.; Artés-Hernández, F. Effects of UV-B and UV-C combination on phenolic compounds biosynthesis in fresh-cut carrots. Postharvest Biol. Technol. 2017, 127, 99-104. [CrossRef]

21. Formica-Oliveira, A.C.; Martínez-Hernández, G.B.; Aguayo, E.; Gómez, P.A.; Artés, F.; Artés-Hernández, F. A functional smoothie from carrots with induced enhanced phenolic content. Food Bioprocess Technol. 2017, 10, 491-502. [CrossRef]

22. Castillejo, N.; Martínez-Zamora, L.; Artés-Hernández, F. Periodical UV-B Radiation Hormesis in Biosynthesis of Kale Sprouts Nutraceuticals. Plant Physiol. Biochem. 2021, 165, 274-285. [CrossRef]

23. Rasband, W. ImageJ-Image Processing and Analysis in Java. Astrophys. Source Code Libr. 2012, 1, 06013.

24. Martínez-Zamora, L.; Castillejo, N.; Artés-Hernández, F. Postharvest UV-B and UV-C Radiation Enhanced the Biosynthesis of Glucosinolates and Isothiocyanates in Brassicaceae Sprouts. Postharvest Biol. Technol. 2021, 181, 111650. [CrossRef]

25. Singleton, V.L.; Rossi, J.A. Colorimetry of Total Phenolics with Phosphomolybdic-Phosphotungstic Acid Reagents. Am. J. Enol. Vitic. 1965, 16, 144-158.

26. Martínez-Zamora, L.; Castillejo, N.; Gómez, P.A.; Artés, F. Amelioration Effect of LED Lighting in the Bioactive Compounds Synthesis during Carrot Sprouting. Agronomy 2021, 11, 304. [CrossRef]

27. Hamed, M.; Kalita, D.; Bartolo, M.E.; Jayanty, S.S. Capsaicinoids, polyphenols and antioxidant activities of Capsicum annuum: Comparative study of the effect of ripening stage and cooking methods. Antioxidants 2019, 8, 364. [CrossRef]

28. Castillejo, N.; Martínez-Hernández, G.B.; Monaco, K.; Gómez, P.A.; Aguayo, E.; Artés, F.; Artés-Hernández, F. Preservation of bioactive compounds of a green vegetable smoothie using short time-high temperature mild thermal treatment. Food Sci. Technol. Int. 2017, 23, 46-60. [CrossRef]

29. Castillejo, N.; Martínez-Zamora, L.; Gómez, P.A.; Pennisi, G.; Crepaldi, A.; Fernández, J.A.; Orsini, F.; Artés-Hernández, F. Postharvest LED lighting: Effect of red, blue and far red on quality of minimally processed broccoli sprouts. J. Sci. Food Agric. 2021, 101, 44-53. [CrossRef]

30. Castillejo, N.; Martínez-Zamora, L.; Artés-Hernández, F. UV radiation enhanced biosynthesis of flavonoids and carotenes in bell peppers. Postharvest Biol. Technol. Postharvest 2022, 184, 111774. [CrossRef]

31. Wellburn, A.R. The Spectral Determination of Chlorophylls a and b, as well as Total Carotenoids, Using Various Solvents with Spectrophotometers of Different Resolution. J. Plant Physiol. 1994, 144, 307-313. [CrossRef]

32. Nelder, J.A. The Fitting of a Generalization of the Logistic Curve. Biometrics 1961, 17, 89-110. [CrossRef]

33. Rogez, H.; Pompeu, D.R.; Akwie, S.N.T.; Larondelle, Y. Sigmoidal kinetics of anthocyanin accumulation during fruit ripening: A comparison between açai fruits (Euterpe oleracea) and other anthocyanin-rich fruits. J. Food Compos. Anal. 2011, 24, 796-800. [CrossRef]

34. Zhong, Y.; Shahidi, F. Methods for the Assessment of Antioxidant Activity in Foods; Elsevier Ltd.: Amsterdam, The Netherlands, 2015; ISBN 9781782420972.

35. Antolovich, M.; Prenzler, P.D.; Patsalides, E.; McDonald, S.; Robards, K. Methods for testing antioxidant activity. Analyst 2002, 127, 183-198. [CrossRef]

36. Kacharava, N.; Chanishvili, S.; Badridze, G.; Chkhubianishvili, E.; Janukashvili, N. Effect of seed irradiation on the content of antioxidants in leaves of Kidney bean, Cabbage and Beet cultivars. Aust. J. Crop Sci. 2009, 3, 137-145.

37. Escobar-Bravo, R.; Klinkhamer, P.G.L.; Leiss, K.A. Interactive effects of UV-B light with abiotic factors on plant growth and chemistry, and their consequences for defense against arthropod herbivores. Front. Plant Sci. 2017, 8, 1-14. [CrossRef]

38. Tohge, T.; Kusano, M.; Fukushima, A.; Saito, K.; Fernie, A.R. Transcriptional and metabolic programs following exposure of plants to UV-B irradiation. Plant Signal. Behav. 2011, 6, 1987-1992. [CrossRef]

39. Zuk-Golaszewska, K.; Upadhyaya, M.K.; Golaszewski, J. The effect of UV-B radiation on plant growth and development. Plant Soil Environ. 2003, 49, 135-140. [CrossRef]

40. Zlatev, Z.S.; Lidon, F.J.C.; Kaimakanova, M. Plant physiological responses to UV-B radiation. Emir. J. Food Agric. 2012, $24,481-501$. [CrossRef]

41. Dou, H.; Niu, G.; Gu, M. Pre-harvest UV-B radiation and photosynthetic photon flux density interactively affect plant photosynthesis, growth, and secondary metabolites accumulation in basil (Ocimum basilicum) plants. Agronomy 2019, 9, 434. [CrossRef]

42. Lim, Y.J.; Jeong, H.Y.; Gil, C.S.; Kwon, S.J.; Na, J.K.; Lee, C.; Eom, S.H. Isoflavone accumulation and the metabolic gene expression in response to persistent UV-B irradiation in soybean sprouts. Food Chem. 2020, 303, 125376. [CrossRef] 
43. Legris, M.; Boccaccini, A. Stem phototropism toward blue and ultraviolet light. Physiol. Plant. 2020, 169, 357-368. [CrossRef] [PubMed]

44. Prior, R.L.; Wu, X.; Schaich, K. Standardized methods for the determination of antioxidant capacity and phenolics in foods and dietary supplements. J. Agric. Food Chem. 2005, 53, 4290-4302. [CrossRef] [PubMed]

45. Drozdowska, M.; Leszczyńska, T.; Koronowicz, A.; Piasna-Słupecka, E.; Dziadek, K. Comparative study of young shoots and the mature red headed cabbage as antioxidant food resources with antiproliferative effect on prostate cancer cells. RSC Adv. 2020, 10, 43021-43034. [CrossRef]

46. Vera, C.; Hinojosa, A.; Tapia, M.L.; Gonzalez, D.; Bustamante, A.; Luchsinger, L.; Escalona, V. Effect of UV-B radiation on the pigments and functional compounds in two cultivars of chard "baby type". Rev. Iberoam. Tecnol. Postcosecha 2014, 15, 193-200.

47. Su, N.; Lu, Y.; Wu, Q.; Liu, Y.; Xia, Y.; Xia, K.; Cui, J. UV-B-induced anthocyanin accumulation in hypocotyls of radish sprouts continues in the dark after irradiation. J. Sci. Food Agric. 2016, 96, 886-892. [CrossRef] [PubMed]

48. Csepregi, K.; Coffey, A.; Cunningham, N.; Prinsen, E.; Hideg, É.; Jansen, M.A.K. Developmental age and UV-B exposure co-determine antioxidant capacity and flavonol accumulation in Arabidopsis leaves. Environ. Exp. Bot. 2017, 140, 19-25. [CrossRef]

49. Chang, C.C.; Yang, M.H.; Wen, H.M.; Chern, J.C. Estimation of total flavonoid content in propolis by two complementary colometric methods. J. Food Drug Anal. 2002, 10, 178-182. [CrossRef]

50. Neugart, S.; Zietz, M.; Schreiner, M.; Rohn, S.; Kroh, L.W.; Krumbein, A. Structurally different flavonol glycosides and hydroxycinnamic acid derivatives respond differently to moderate UV-B radiation exposure. Physiol. Plant. 2012, 145, 582-593. [CrossRef]

51. Neugart, S.; Hideg, É.; Czégény, G.; Schreiner, M.; Strid, Å. Ultraviolet-B radiation exposure lowers the antioxidant capacity in the: Arabidopsis thaliana pdx1.3-1 mutant and leads to glucosinolate biosynthesis alteration in both wild type and mutant. Photochem. Photobiol. Sci. 2020, 19, 217-228. [CrossRef]

52. Topcu, Y.; Dogan, A.; Sahin-Nadeem, H.; Polat, E.; Kasimoglu, Z.; Erkan, M. Morphological and biochemical responses of broccoli florets to supplemental ultraviolet-B illumination. Agric. Ecosyst. Environ. 2018, 259, 1-10. [CrossRef]

53. Takshak, S.; Agrawal, S.B. Defense potential of secondary metabolites in medicinal plants under UV-B stress. J. Photochem. Photobiol. B Biol. 2019, 193, 51-88. [CrossRef]

54. Singh, J.; Upadhyay, A.K.; Bahadur, A.; Singh, B.; Singh, K.P.; Rai, M. Antioxidant phytochemicals in cabbage (Brassica oleracea L. var. capitata). Sci. Hortic. 2006, 108, 233-237. [CrossRef]

55. Singh, J.; Upadhyay, A.K.; Prasad, K.; Bahadur, A.; Rai, M. Variability of carotenes, vitamin C, E and phenolics in Brassica vegetables. J. Food Compos. Anal. 2007, 20, 106-112. [CrossRef]

56. He, W.; Wang, Y.; Dai, Z.; Liu, C.; Xiao, Y.; Wei, Q.; Song, J.; Li, D. Effect of UV-B radiation and a supplement of CaCl 2 on carotenoid biosynthesis in germinated corn kernels. Food Chem. 2019, 278, 509-514. [CrossRef]

57. Tian, S.L.; Li, L.; Shah, S.N.M.; Gong, Z.H. The relationship between red fruit colour formation and key genes of capsanthin biosynthesis pathway in Capsicum annuum. Biol. Plant. 2015, 59, 507-513. [CrossRef]

58. Llorente, B.; Martinez-Garcia, J.F.; Stange, C.; Rodriguez-Concepcion, M. Illuminating colors: Regulation of carotenoid biosynthesis and accumulation by light. Curr. Opin. Plant Biol. 2017, 37, 49-55. [CrossRef]

59. Martínez-Zamora, L.; Castillejo, N.; Artés, F. Postharvest UV-B and Photoperiod with Blue + Red LEDs as Strategies to Stimulate Carotenogenesis in Bell Peppers. Appl. Sci. 2021, 11, 3736. [CrossRef] 